4 


\section{Lessons Learned}

from the

\section{Urban Forestry \\ Climate Change Response Framework Project}

\section{Authors}

LESLIE BRANDT is a climate change specialist with the U.S. Forest Service, Northern Institute of Applied Climate Science, 1992 Folwell Avenue, St. Paul, MN 55108, Ibrandt@fs.fed.us

LYDIA SCOTT is director of the Chicago Region Trees Initiative at The Morton Arboretum, 4100 Illinois

ABIGAIL DERBY LEWIS is a conservation ecologist at Keller Science Action Center, The Field Museum, $1400 \mathrm{~S}$. Lake Shore Drive, Chicago, IL 60605, aderby@fieldmuseum.org

LINDSAY DARLING is a GIS analyst with the Morton Arboretum, 4100 IL Rt. 43, Lisle, IL 60532, Idarling@ mortonarb.org

ROBERT FAHEY is an Assistant Professor in the Department of Natural Resources and the Environment \& the Center for Environmental Sciences and Engineering at the University of Connecticut, 1376 Storrs Rd., Storrs, CT 06269, robert.fahey@uconn.edu

\section{Acknowledgments}

Thanks to P.D. Shannon and K. Marcinkowski for assistance with maps, figures, and document design.

Funding for this work was provided by the US Forest Service, Chicago Wilderness, The Morton Arboretum, The Field Museum, and the Chicago Region Trees Initiative.

Suggested Citation: Brandt, L.; Scott, L.; Derby Lewis, A.; Darling, L.; Fahey R. 2016. Lessons learned from the Urban Forestry Climate Change Response Framework. Houghton, MI: Northern Institute of Applied Climate Science. $36 \mathrm{pp}$.

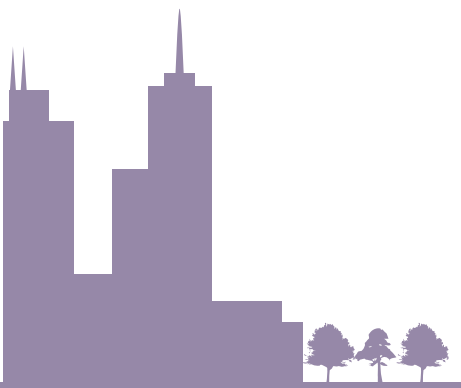





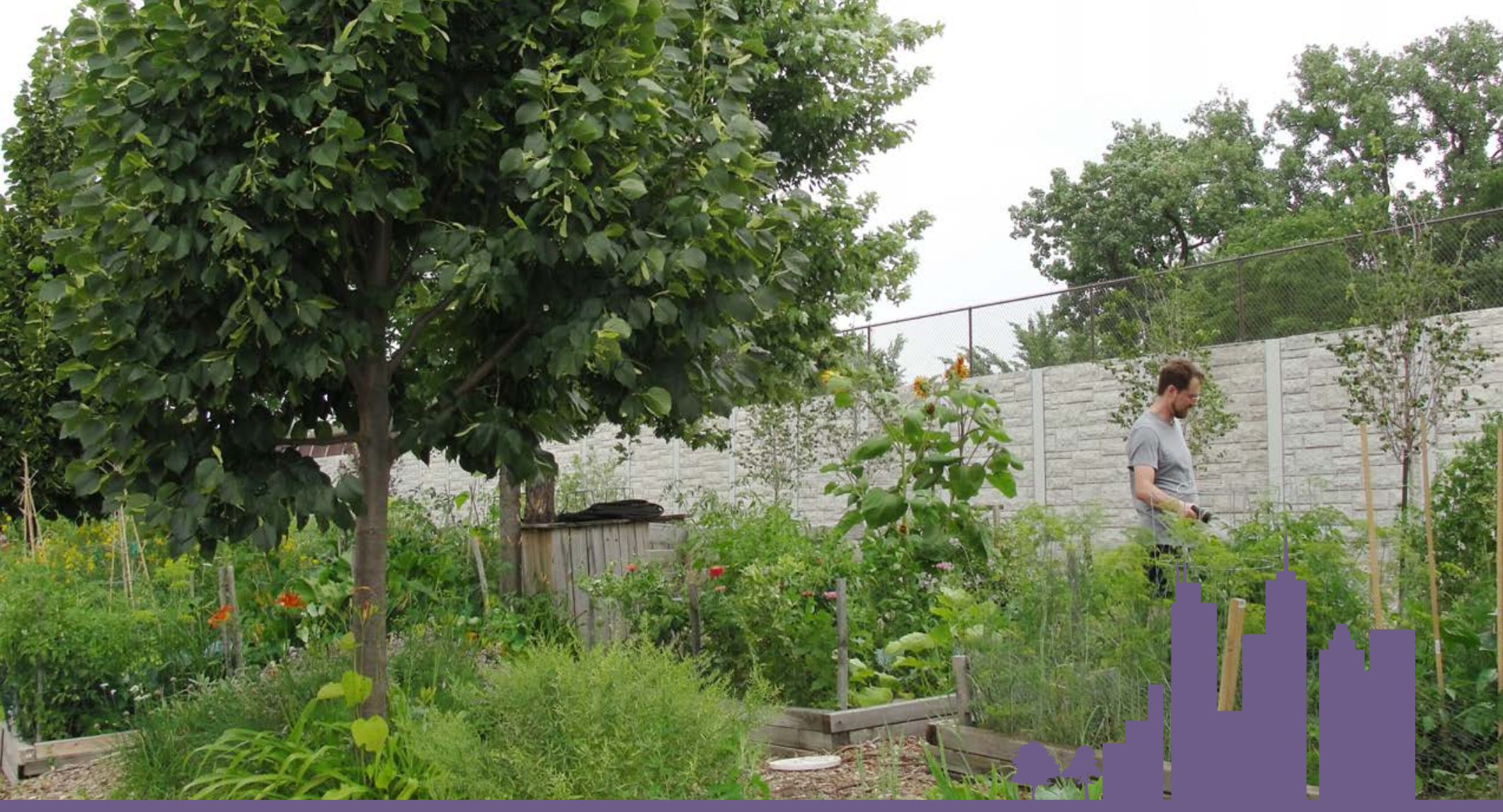

\section{ntroduction}

Urban areas are already experiencing impacts of a changing climate including increased temperatures, flooding, and extreme storms. These impacts are projected to increase in frequency and magnitude over the next century, leading many cities to develop plans to adapt and prepare for these challenges. Increasing tree canopy is often considered in urban climate change adaptation plans, where trees can help reduce local heat island effects, control storm water, and improve air quality.

Although urban trees can be an important part of adaptation solutions, they also can be vulnerable to the impacts of climate change. Harsher summer temperatures, potential summer droughts, heavy winds, flooding, and increased pests and diseases can all stress urban trees. These urban trees may be experiencing stress from improper planting, restricted rooting conditions, road salt, and air pollution already, and therefore extremely vulnerable to climate change.

Many urban foresters have recognized the need to incorporate climate change considerations into urban forest management, but often lack the specialized training or knowledge to explicitly address this in their planning and practices.

This document describes a framework we developed and piloted in the Chicago region to assess the vulnerability of urban forests and incorporate that information into on-theground actions. We describe the three steps used to implement this project and the lessons learned from this process. Our hope is that by sharing our experience, others can learn from it and apply this framework to their own urban areas. 
Fig. 2. Project area.

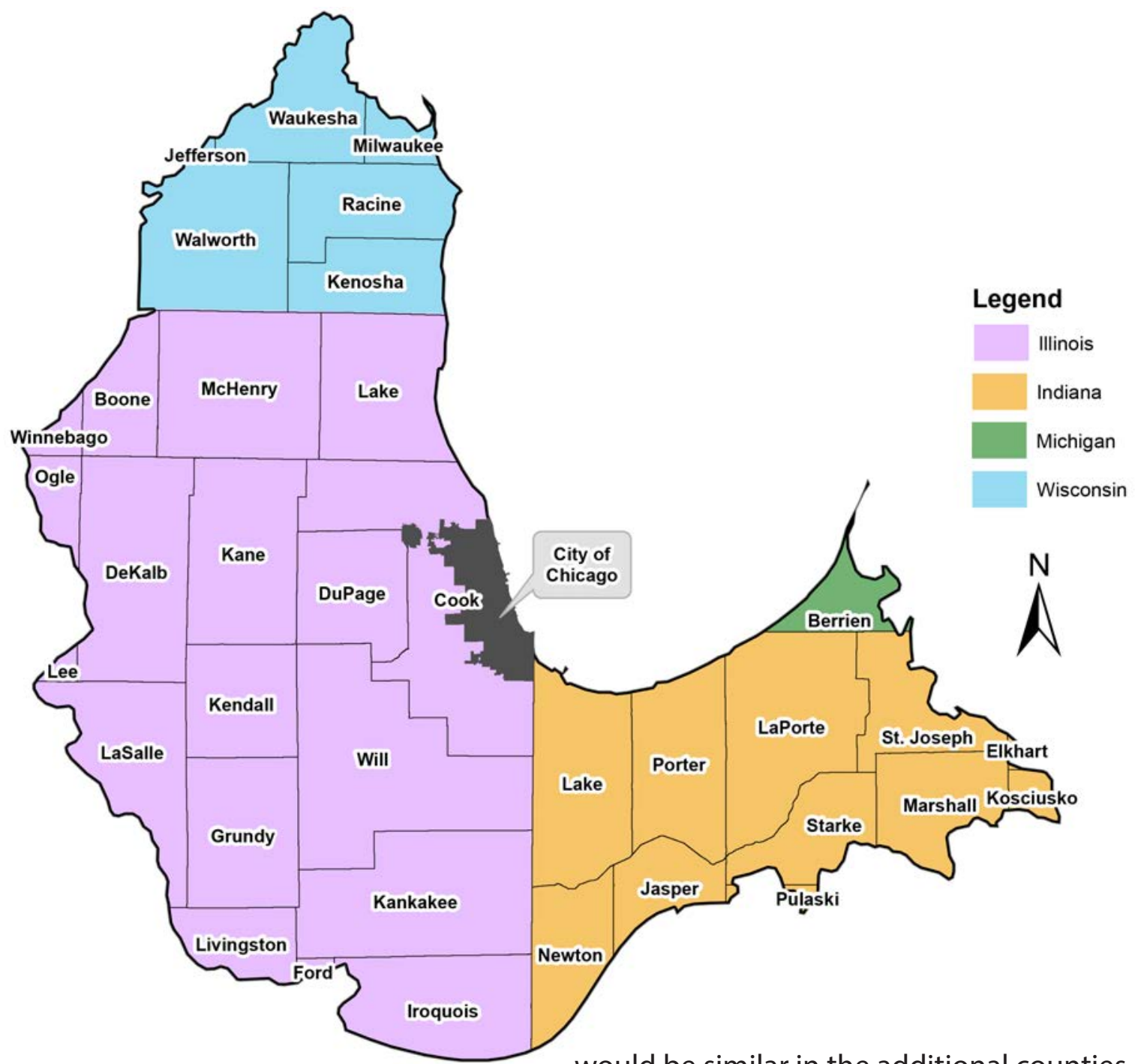

would be similar in the additional counties not

We used the Chicago Wilderness region as the assessment area boundary (Fig 2.). Chicago Wilderness is a regional alliance of organizations with a goal "to preserve, improve, and expand nature and quality of life in parts of Illinois, Indiana, Wisconsin, and Michigan." We chose this boundary because it was already familiar to our local partner organizations, had clear borders, and encompassed the entire metropolitan area of Chicago.

The number of species and cultivars in urban areas can be overwhelming. We narrowed the number of species to a manageable number by compiling a list of the 120 most common trees in the seven-county region surrounding Chicago as determined by a recently published Regional Tree Census (Nowak et al. 2013). We used this smaller area because we did not have data for the entire Chicago Wilderness region, and we assumed that species composition represented in the seven-county area. Because we were also interested in the vulnerability of species being recommended for planting locally, we evaluated 59 additional species and cultivars recommended on The Morton Arboretum's Northern Illinois Tree Species List (The Morton Arboretum 2015).

We defined vulnerability as the degree to which a system is susceptible to, and unable to cope with, adverse effects of climate change, including climate variability and extremes, summarized as a function of the system's impacts (exposure and sensitivity) and adaptive capacity (Fig. 3; Glick et al. 2011, IPCC 2014). We defined impacts as the direct effect of current and projected changes in temperature and precipitation on a particular species. Adaptive capacity was defined as the ability of a species to cope with both direct and indirect impacts of climate change. 


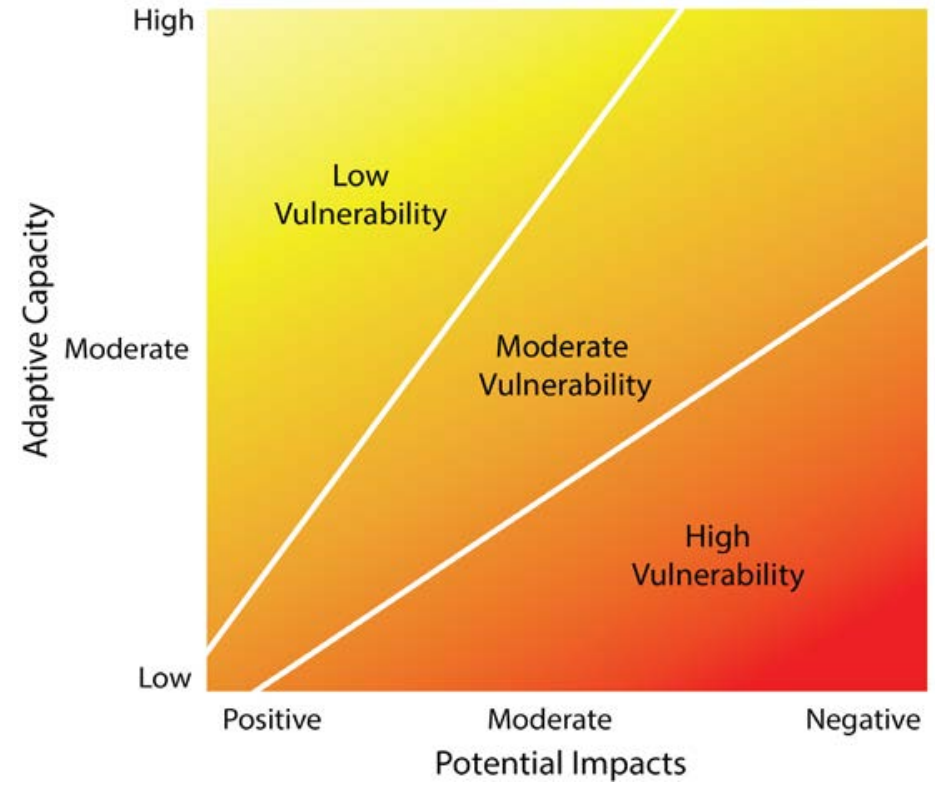

Fig. 3. Figure depicting vulnerability as a function of impacts and adaptive capacity (based on Swanston and Janowiak 2012).

\section{Assessing Impacts}

We used a suite of quantitative approaches to assess climate change impacts to individual tree species. For native species, we used species distribution model projections from the "Climate Change Tree Atlas" ("Tree Atlas") (Iverson et al. 2008, Landscape Change Research Group 2014) for 70 species native to the United States that are either currently present in the Chicago Wilderness region or likely to have suitable habitat in the area in the future. Changes in suitable habitat were projected through the end of the 21 st Century for the region under two model-emission scenario combinations (PCM B1 and GFDL A1FI, Stoner et al. 2013). The model scenarios were chosen to bracket a range of potential futures of minimal warming with wetter summers to considerable warming with drier summers. The timeframe was chosen because this was the longest time period for which there was any reasonable certainty in climate model projections yet still covered much of the lifespan of many urban trees.
For the remaining non-native species and cultivars (where species distribution models were unavailable), we compared the known heat and hardiness zone ranges of species to projected shifts in heat and hardiness zones under the same two model/scenario combinations in the Tree Atlas. When the heat zone was projected to be at or above the threshold of the species or cultivar over its lifespan, a decrease in habitat suitability was projected. A species was considered to have an increase in habitat suitability if projected hardiness zones were at or above a species minimum threshold over the species' lifespan.

\section{Assessing Adaptive Capacity}

We evaluated adaptive capacity of each species or cultivar using a scoring system based on a literature review, which was modified from a system created by the Landscape Change Research Group as a complement to the Tree Atlas model results (Matthews et al. 2011). This approach evaluates species' life history traits and tolerance to disturbances (fig. 4). It was originally developed for native trees in natural areas, but we expanded it to include non-native species and cultivars. We created separate scores for natural and developed urban sites. The scoring system for natural areas was very similar to the original scores developed by Matthews et al. (2011). The scores for developed site scores included considerations specific to urban areas, such as planting site specificity, nursery production potential, and maintenance required (Brandt et al., in review). Thus, a species or cultivar could have an entirely different adaptive capacity based on whether it is naturally-occurring or planted in a highly developed area. Information for adaptive capacity was synthesized from the scientific and gray literature. Individual scores were reviewed by local experts in urban forestry. 


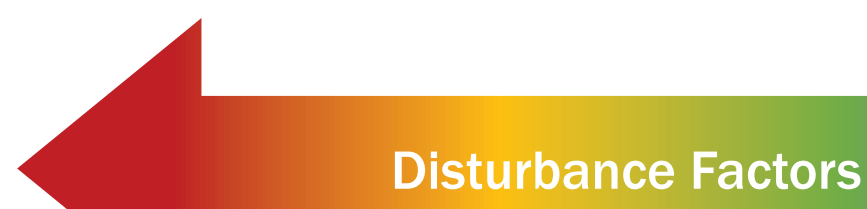

Pest, disease, fire, drought, flood, pollution, heat, herbivory, invasive species, salt resistance

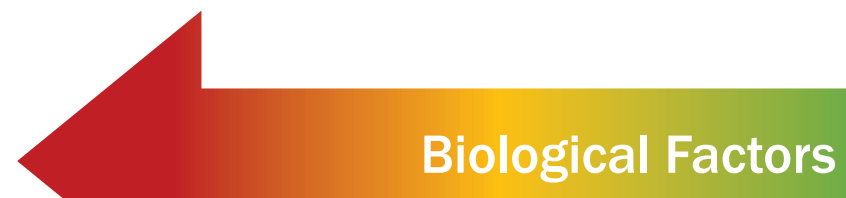

Shade tolerance, edaphic specificity, propagation, pruning needed, establishment, rooting conditions

\section{$-3$}

0

3

Fig. 4. Adaptive capacity factors used in the assessment. Negative scores meant it reduced a species' adaptive capacity. Positive meant it increased a species adaptive capacity.

\section{Assessing Vulnerability}

We used the information compiled above to develop a vulnerability rating for each species. We placed all species evaluated into one of five vulnerability categories (low, low-moderate, moderate, moderate-high, or high).

For species where information was available from the Tree Atlas, the following matrix was used to determine vulnerability:

\begin{tabular}{|c|c|c|c|}
\hline & \multicolumn{3}{|c|}{ Adapt Class } \\
\hline $\begin{array}{l}\text { Projected Change in Habitat } \\
\text { Suitability (Tree Atlas) }\end{array}$ & Low & Medium & High \\
\hline decrease (both scenarios) & high & moderate-high & moderate \\
\hline mixed results & moderate-high & moderate & low-moderate \\
\hline no effect & moderate-high & low-moderate & low \\
\hline increase (both scenarios) & moderate & low-moderate & low \\
\hline
\end{tabular}

For species where no model information was available, the following matrix was used to determine vulnerability:

\section{Adapt Class}

$\begin{array}{llll}\text { Heat/Hardiness Zone Effect } & \text { Low } & \text { Medium } & \text { High } \\ \text { negative } & \text { high } & \text { moderate-high } & \text { moderate } \\ \text { no effect } & \text { moderate-high } & \text { low-moderate } & \text { low } \\ \text { positive } & \text { moderate } & \text { low-moderate } & \text { low }\end{array}$




\section{Regional Literature Review}

We also conducted an extensive literature review to complement the species-level assessment, summarizing past and projected climate change impacts in the region and projected effects on the region's urban forest (Brandt et al., in press). A literature search of both the peer-reviewed and gray literature was compiled using key word searches in ISI Web of Knowledge (www.webofknowledge.com) and Google Scholar (scholar.google.com) with key words including "climate change", "climate", "urban forest", "Chicago", and "Midwest." We developed summaries of the key impacts of climate change on the region's urban forest based on themes that emerged from the literature review and those identified by collaborators. We included these summaries as part of the written assessment document (Brandt et al, in review).

\section{Step 2:}

\section{Local Vulnerability Assessments}

Our second step was to work with local urban forestry practitioners to step down the regional information to make it more locally relevant. We piloted this process in a one-day workshop with municipal foresters, planners, park managers, and other urban and community forestry professionals. We solicited participants from seven counties in the Chicago region - Lake, McHenry, Kane, Cook, DuPage, Kendall and Will. We included a wide variety of land managers at the community scale, which included municipalities, townships, county forest preserves and park districts. Ultimately four municipalities, three park districts, and three forest preserves participated (fig. 5).

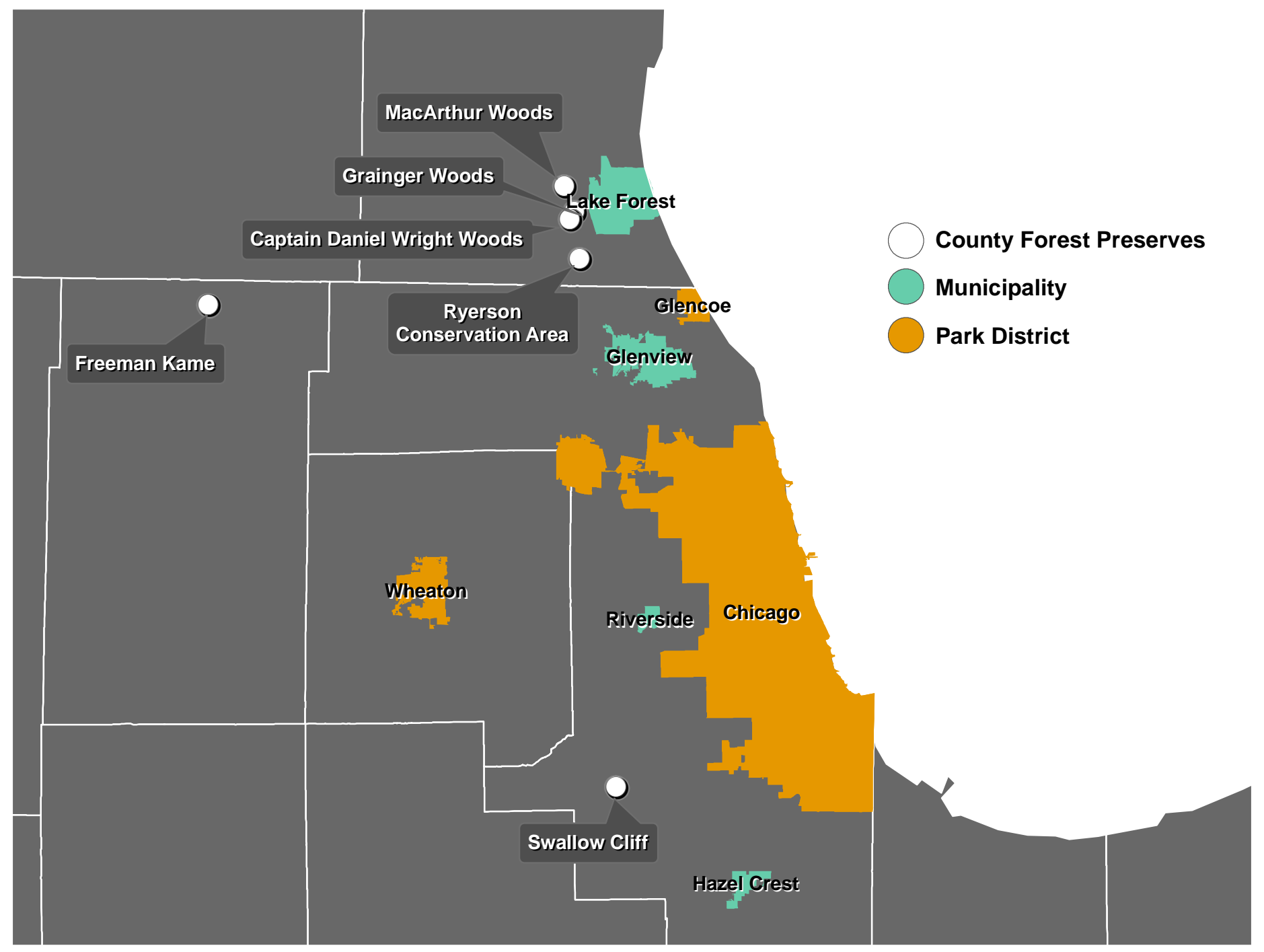


We developed a self-assessment worksheet for the workshop (see Appendix 2) that bridged regional impacts and adaptive capacity factors to a local scale, using concepts developed by Ordóñez and Duinker (2014). We asked participants to assess how regional impacts (the sum of exposure and sensitivity; Glick et al. 2011) may differ at the local level when modified by local factors in three dimensions: physical, biological, and human (fig. 6). Physical factors included the specific soil and geomorphic conditions of the area and its relative closeness to Lake Michigan. Biological factors included the tree species composition and the presence or threat of pests and diseases that could be affected by climate change. Human factors included urban heat island effects, relative ozone pollution, and amount of impervious cover.

We defined adaptive capacity as the general ability of institutions, systems, and individuals to moderate the risks of climate change or to realize benefits through changes in their characteristics or behavior. We asked participants to evaluate adaptive capacity in four dimensions: organizational/ technical, biological, economic, and social. Organizational/technical factors included staffing, level of planning and preparedness

Fig. 6. Factors assessed in local vulnerability assessments.

\section{Impacts}

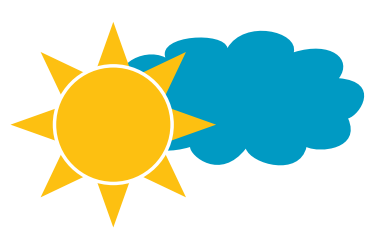

Physical factors

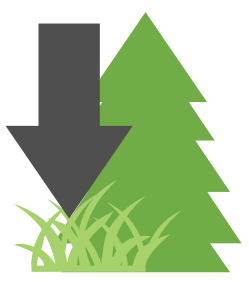

Biological factors

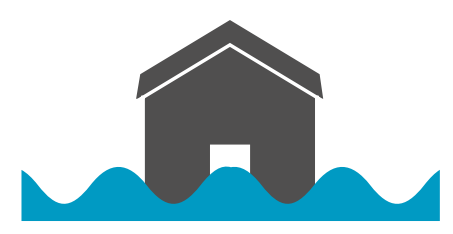

Human factors for disasters, and level of planting and maintenance. Biological factors included the diversity of species, genotypes, and age classes in the area. Economic factors included the extent to which funds are available for planting and care. Social factors were the level of public involvement and support for urban forestry activities in the area.

We developed a one day workshop format for completing the vulnerability worksheets (see Appendix 1 for agenda). The morning of the workshop was devoted to presentations by experts on climate change impacts and adaptive capacity of tree species in the region. An overview of trends and projections in regional climate change was also provided. We then provided all participants with thorough instructions on how to complete the vulnerability worksheets. Participants were divided into three groups (municipalities, parks, and forest preserves) and each group was assigned a facilitator and recorder.

Participants each completed their own assessments in their groups, but shared their thoughts and responses throughout the process. Participants were also asked to provide inventories, if available, which we analyzed for tree species vulnerability based on the process described in Step 1.

\section{Adaptive Capacity}

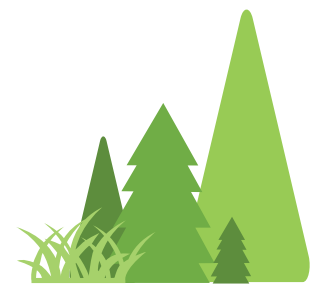

Biological factors

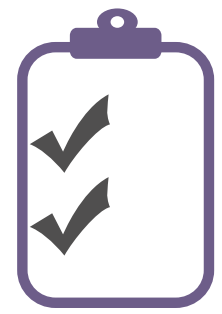

Organizational/technical factors

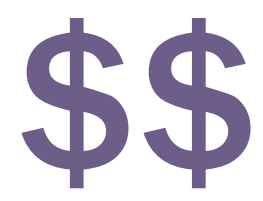

Economic factors

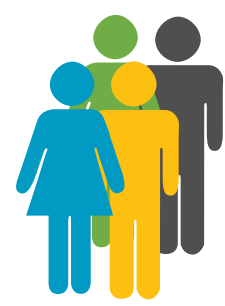

Social factors 


\section{Adaptation Projects and Planning}

This step takes vulnerability information developed by practitioners and asks them to incorporate it into specific planning efforts or projects. The participants from the vulnerability workshop participated in one-day adaptation planning workshop two months following the vulnerability workshop. Each participant was asked to consider a specific on-the-ground project or planning effort in a structured adaptation process.

Prior to the adaptation workshop, we asked each participating organization to identify a specific planning process, project, or program that they wanted to evaluate in the workshop. When possible, we had one-on-one conversations with participants to review the project they selected. We also asked them to do some pre-work to identify the project goals and objectives to help jumpstart the workshop process.

We walked participants through a structured adaptation process where they defined their goals and objectives, incorporated their vulnerability assessment information, identified challenges and opportunities for their project due to current or projected climate change, selected potential adaptation strategies from a menu of peer-reviewed options, and developed potential on-the-ground tactics. We based our process on the adaptation workbook developed by Swanston and Janowiak (2012). We modified this process from the original in two key ways. First, we provided a list of 31 potential adaptation strategies specific to urban forests (Swanston et al., in press), based on a menu of adaptation strategies developed for natural systems (Swanston and Janowiak 2012). The Chicago Wilderness Trees and Green Infrastructure Task Force reviewed this list and adjusted language, supporting literature, and examples for an urban audience. Second, we focused only on the first four steps of the adaptation workbook developed by Swanston and Janowiak (2012), omitting the monitoring component (fig. 7). Monitoring was omitted both in the interest of time and also because monitoring did not apply to all the projects identified (e.g. developing species lists, updating nursery stock).

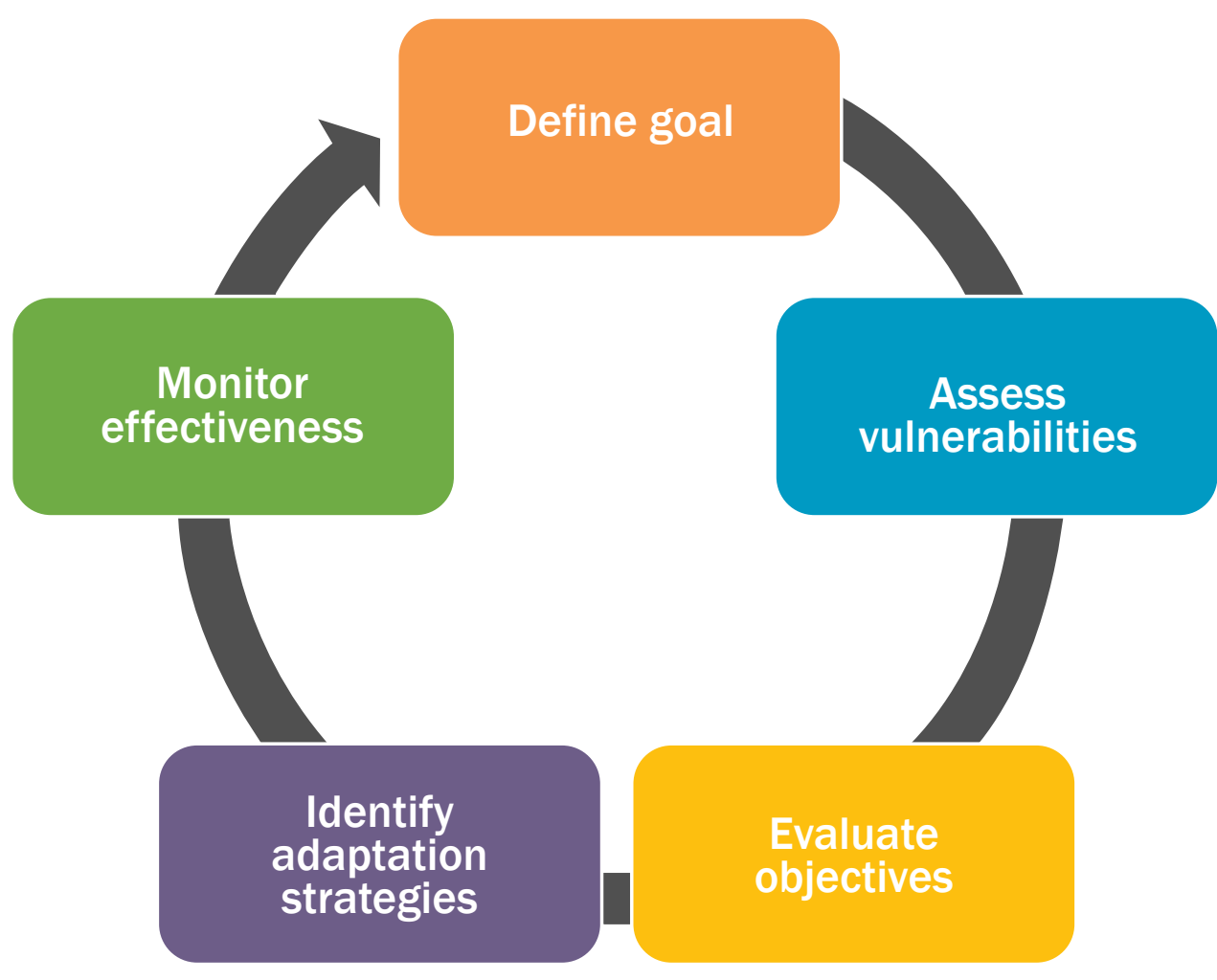

Fig 7. Adaptation workbook process. 


\section{Organization}

A project coordinator from the Northern Institute of Applied Climate Science (Leslie Brandt) led all three steps of the project, spending an average of 50 percent of her time on the project (Table 1). Two local representatives from the Morton Arboretum and the Field Museum also contributed significantly to the project. The local representatives had expertise and local connections in urban forestry and climate change adaptation, respectively. They helped with overall project design, recruitment of workshop participants, writing, and review. We also had a broader group of collaborators that contributed to large parts of the effort. Additional experts in urban forestry and forest ecology from the Morton Arboretum and Field Museum contributed writing, project design ideas, review, and workshop assistance. The Landscape Change Research Group at the Forest Service Northern Research station developed heat and hardiness zone projections and provided assistance on the adaptation scoring system. A scientist from The Davey Tree Expert Company summarized Tree Atlas information for the Chicago Wilderness region. Scientists from the Chicago Botanic Garden also contributed projections for habitat suitability of trees in cultivated settings. Additional scientists from the Field Museum, Forest Service, and the Morton Arboretum also contributed presentations, writing, and expertise. There was also a large group of additional contributors. Experts in climate change adaptation from the Northern Institute of Applied Climate Science also provided assistance on project design and produced maps and other images for the project. Urban forestry professionals provided input on adaptation strategies and participated in the workshops.

Table 1. Project Organization

KEY ROLES

NUMBER CONTRIBUTIONS (\% FTE)

\begin{tabular}{|c|c|c|c|}
\hline $\begin{array}{l}\text { PROJECT } \\
\text { COORDINATOR }\end{array}$ & $\begin{array}{l}\text { Manage project, lead author of reports, design and lead } \\
\text { workshops, key lead on project design }\end{array}$ & 1 & 50 \\
\hline $\begin{array}{l}\text { LOCAL } \\
\text { REPRESENTATIVE(S) }\end{array}$ & $\begin{array}{l}\text { Engage local community, write large report sections, } \\
\text { help organize and execute workshops }\end{array}$ & 2 & $10-15$ \\
\hline $\begin{array}{l}\text { KEY } \\
\text { COLLABORATORS }\end{array}$ & $\begin{array}{l}\text { Provide model projections, input on scientific process, } \\
\text { contribute writing, workshop assistance }\end{array}$ & 10 & $5-10$ \\
\hline $\begin{array}{l}\text { OTHER } \\
\text { CONTRIBUTORS }\end{array}$ & $\begin{array}{l}\text { Contribute expertise, data or images; participate in } \\
\text { workshops }\end{array}$ & 20 & $1-5$ \\
\hline
\end{tabular}




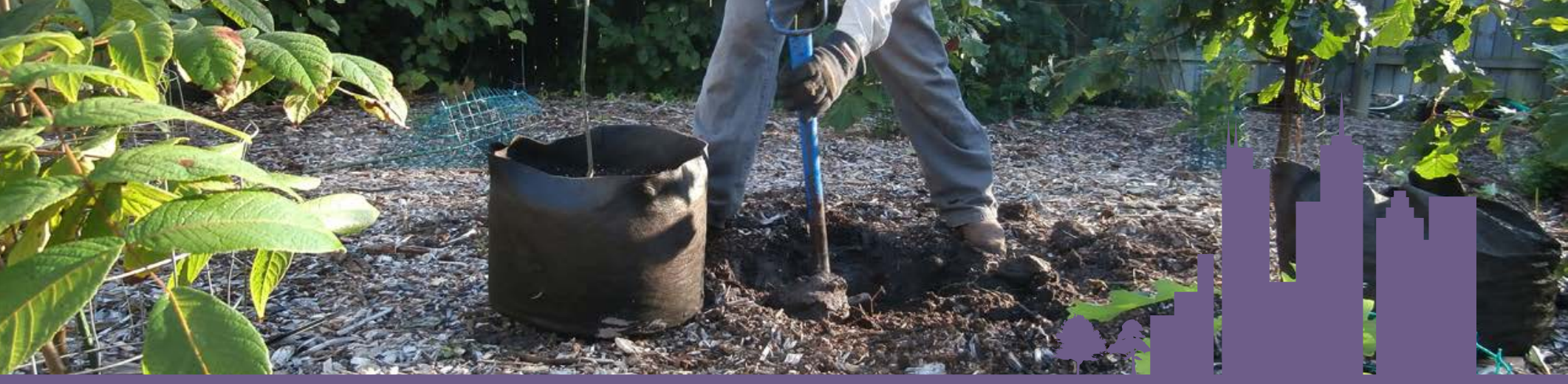

itmeitne

The project took roughly two years to complete (Table 2). The regional vulnerability assessment took the most time, and much of this time was spent figuring out methods. If subsequent projects were undertaken using the same methods, we believe the time could have been shortened substantially. At minimum, several months to a year would be needed to plan, execute, and follow up from the workshops.

Table 2. Timeline.

\begin{tabular}{|c|c|c|c|c|c|c|c|c|c|}
\hline & \multicolumn{4}{|c|}{2014} & \multicolumn{4}{|c|}{2015} & \multirow{2}{*}{2016} \\
\hline $\begin{array}{l}\text { Project } \\
\text { Components }\end{array}$ & Spring & Summer & Fall & Winter & Spring & Summer & Fall & Winter & \\
\hline $\begin{array}{l}\text { Regional } \\
\text { Vulnerability } \\
\text { Assessment }\end{array}$ & $\begin{array}{c}\text { Initial } \\
\text { planning } \\
\text { meeting, } \\
\text { develop } \\
\text { assess- } \\
\text { ment } \\
\text { methods }\end{array}$ & $\begin{array}{l}\text { Modeling, } \\
\text { adap- } \\
\text { tation } \\
\text { scoring }\end{array}$ & $\begin{array}{l}\text { Prelim- } \\
\text { inary } \\
\text { modeling, } \\
\text { adap- } \\
\text { tation } \\
\text { results } \\
\text { complete }\end{array}$ & \multicolumn{2}{|c|}{$\begin{array}{l}\text { Final modeling, ad- } \\
\text { aptation results, write } \\
\text { report }\end{array}$} & $\begin{array}{l}\text { Submit for } \\
\text { technical } \\
\text { review }\end{array}$ & $\begin{array}{l}\text { Edit final } \\
\text { version }\end{array}$ & \multicolumn{2}{|c|}{ External review } \\
\hline $\begin{array}{l}\text { Local } \\
\text { Vulnerability } \\
\text { Assessments }\end{array}$ & & $\begin{array}{c}\text { Develop } \\
\text { Assess- } \\
\text { ment } \\
\text { methods, } \\
\text { invite } \\
\text { communi- } \\
\text { ties }\end{array}$ & $\begin{array}{c}\text { Plan, hold } \\
\text { vulner- } \\
\text { ability } \\
\text { workshop }\end{array}$ & $\begin{array}{l}\text { Sumerize } \\
\text { results }\end{array}$ & & & & & \\
\hline $\begin{array}{l}\text { Adaptation } \\
\text { Projects }\end{array}$ & & $\begin{array}{l}\text { Plan, pub- } \\
\text { licize }\end{array}$ & $\begin{array}{l}\text { Hold } \\
\text { training }\end{array}$ & $\begin{array}{c}\text { Hold } \\
\text { workshop }\end{array}$ & Follow-up & $\begin{array}{l}\text { with commu } \\
\text { ries for }\end{array}$ & $\begin{array}{l}\text { nities, write } \\
\text { he web }\end{array}$ & p summa- & $\begin{array}{l}\text { Apply for } \\
\text { imple- } \\
\text { mentation } \\
\text { funding }\end{array}$ \\
\hline Outreach & \multicolumn{2}{|c|}{$\begin{array}{l}\text { Create key messages, } \\
\text { web page, get stake- } \\
\text { holder imput }\end{array}$} & \multicolumn{2}{|c|}{$\begin{array}{l}\text { Publicize workshops, } \\
\text { reach out to partici- } \\
\text { pants }\end{array}$} & \multicolumn{5}{|c|}{$\begin{array}{l}\text { Present reults at local, national meeting, post materials on } \\
\text { web }\end{array}$} \\
\hline
\end{tabular}



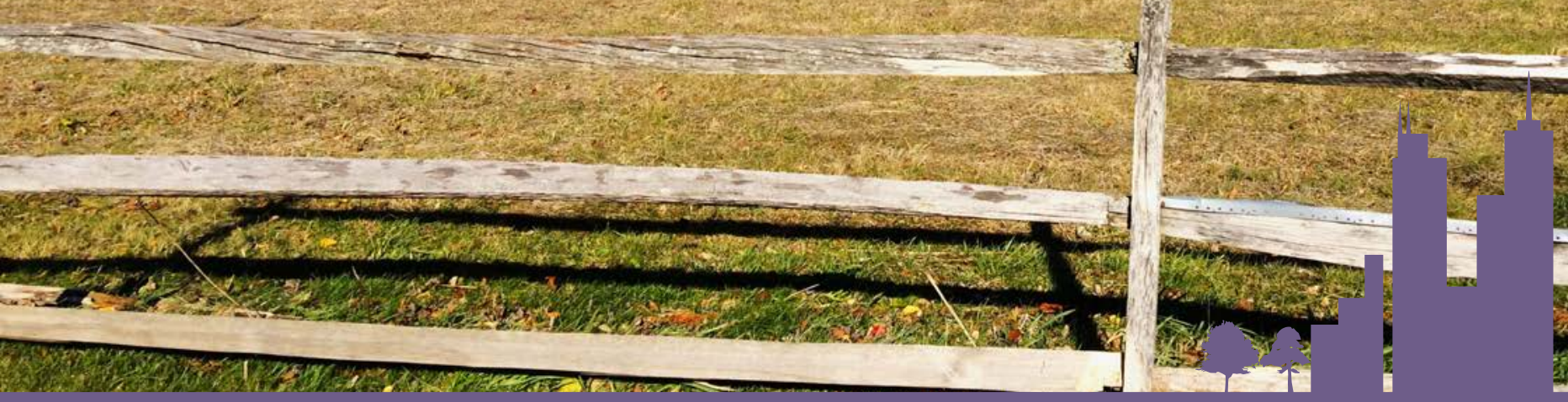

Lessons Learned

\section{Regional Vulnerability Assessment}

Determine regional boundaries early

It is important to define the geographic extent of the project early in the process. The Chicago Wilderness region had clearly defined boundaries based on watersheds that were familiar to our collaborators, so our project area was relatively simple to define. For other metropolitan regions, it may make sense to use boundaries defined by regional planning entities, other metropolitan greenspace organizations, or metropolitan statistical areas defined by the US Office of Management and Budget.

\section{Know your regional tree composition}

In order to know how many and which species are vulnerable, an estimate of regional tree species composition is needed. We were fortunate to have the results from the Regional Tree Census to estimate the current species composition for the region. This information did not perfectly align with the boundaries of the Chicago Wilderness region, so we had to make assumptions that the species composition would be similar across the larger area. Also, because the "census" was actually a sample and not a complete inventory, it did not catch all of the species in the region. Most (or perhaps all) metropolitan regions will not have a complete inventory of their trees. So make use of samples or partial inventories to estimate their composition as best you can. It may be necessary to compile datasets from multiple municipalities, which could add to the time needed to implement the project.

\section{High number of cultivars, nonnative species adds challenges}

Most urban areas have many trees that are not native to their region, including cultivars or trees native to other parts of North America or other continents. This increases the species richness beyond what would occur naturally, meaning there are many more trees to assess for vulnerability than one would typically assess in natural areas. In some cases, planted species are relatively rare (or entirely absent) in nature, making it difficult to know much about their ecology or tolerance of large-scale disturbances. Some cultivars can be hard to identify in inventories, making it hard to tell how many exist in the sample. In addition, little may be known about the long-term tolerance of disturbance events for newer cultivars. This diverse mix of species and cultivars means that there may be greater uncertainty in estimates of vulnerability for urban trees over their rural counterparts.

\section{Habitat suitability models have their limits in urban areas}

We originally thought that it would be possible to develop habitat suitability models for urban trees under future climate scenarios, but quickly learned there were many factors that made this challenging. In order to parameterize these models, a good estimate of the species' 
climatic envelope is needed. This is not always possible for many of the nonnative species and cultivars. In addition, local urban environments can be very different than the surrounding natural environments for urban trees, including heat islands, local flooding from impervious cover, and altered soil conditions. Residents and municipalities may also water trees during dry periods, allowing many trees to survive in areas where it would otherwise be too dry. Thus, trees in urban environments may respond very differently than models based on natural habitat would predict. Information on species' heat and hardiness zone ranges along with assessments of their adaptive capacity were shown to be much more important than quantitative modeling in the final assessment.

\section{Mix of land uses and cover makes generalizations difficult}

Urban areas have a mix of land use and land cover types that range from highly developed to relatively pristine, with much variationin between. Differences in topography, soils, impervious cover, economic factors, and local differences in age class and tree condition can all lead to differences in vulnerability for an urban forest. When assessing vulnerability over a large region, much of this complexity will be lost. This is why the local assessments we did in step 2 were so critical.

\section{Community Vulnerability Workshop}

\section{Get the right people in the room}

We wanted to target municipal foresters and planners, parks departments, and forest preserve managers who manage large amounts of land within the region. We spent a lot of time personally reaching out to communities to participate in the workshop via in-person meetings, emails, and phone calls. Despite these efforts, it was not possible to get everyone we had originally wanted to participate in the workshop. There were a number of constraints, including competing demands, travel distance, scheduling conflicts, and lack of support for engaging in climate change activities. Many of the people who were able to participate were from more affluent areas and/or communities that had already been engaged on climate change issues. The stakeholders who were able to participate were likely from communities that may be less vulnerable because they have the time, means, and will to engage in activities to prepare for climate change.

Ensure regional assessment results are vetted and finalized beforehand

We underestimated the amount of time that would be needed to finalize results from the habitat suitability models and adaptive capacity scores used in the regional assessment. Our goal had been to provide these results, and ideally summarize tree species vulnerability, for each participating community based on their provided inventories. Despite careful planning, preliminary model results were not complete until a few days before the workshop and the adaptive capacity scores for many species had not yet been reviewed. The workshop was thus the first opportunity for those of us engaged in the regional assessment to review the results and identify inevitable errors.

Many participants expressed frustration with model inconsistencies and would have been more comfortable in seeing the final, polished product.

\section{Inventory data are extremely important}

Inventories are crucial to know how many species are vulnerable to climate change, how diverse the species composition is, the general age or condition class of the trees, and spatial variation in species composition. Not all participating communities had inventories, which lowered the overall certainty of their local vulnerability assessments. Of those that did have inventories, there was substantial variability in the range of what was included (e.g., just street trees, parks, or both), the age of the inventory, types of information collected, and whether or not the trees were geospatially referenced. Ideally, every community would have a complete, up to date, georeferenced inventory that included tree size and condition in addition to species identification for both private and public spaces. However, a complete inventory that include all private lands is 
unlikely to ever become a reality. Scientificallyrigorous sampling methods used in i-Tree (www.itreetools.org)) or the Forest Service's Urban Forest Inventory and Analysis may be helpful to estimate numbers when complete inventories are not feasible.

\section{Adaptation Projects}

\section{Give ample time for pre-work}

Ideally, communities will be given ample time to fully develop their project ideas prior to attending the adaptation workshop. Due to scheduling constraints, our adaptation workshop was held less than two months after the vulnerability workshop, with a busy holiday season in between. This made it challenging for communities to fully digest the outcomes of the vulnerability workshop and consider appropriate projects for the adaptation workshop. In the future, we would suggest several months lead time for project identification and planning to ensure that communities come prepared. Ideally, we would have also had a pre-workshop webinar with participants to explain the pre-work they needed to complete prior to attending the workshop. Because we did not do this, many participants had not completed the pre-work we had requested.

\section{Make your expectations clear to participants}

Our goal was to use results from the adaptation workbook as examples we could share on our website. We asked participants to spend a few weeks writing up their workbook results and to email them back to us. The majority of participants sent back their workbooks as requested. Some of them did not end up sending us their final results. Some sent us workbooks that were not fully complete. Others did not want their information shared publicly. There may have been ways to increase the workbook completion rate, such as taking more time in the workshop and having them turn them in at the end.

Follow up with participants often

Participants walked away from the workshop with many ideas of how they would adapt to climate change, but few had solidified them into concrete actions at the end of the workshop. Follow up meetings or phone calls several months after the workshop, and perhaps quarterly afterward, would have helped participants stay engaged as they moved from ideas to actions.

\section{Overall}

Establish goals, outcomes, timelines, and roles early, and re-evaluate often

Early on in our process, we held a meeting with key project collaborators and stakeholders. We described the vision for the project and specific goals and objectives. Scientists presented key pieces of information they could provide as inputs into the vulnerability assessment and asked for feedback from participants on the project focus. We also assigned roles and responsibilities and a timeline at that time. As the project moved on, however, it would have been helpful to revisit what had been agreed upon regularly throughout the process to ensure we were on track.

\section{Interested and engaged local contacts are key to success}

One of the things that made our project successful was having local collaborators that were widely engaged with the community. They could build on relationships already developed to recruit participants for the workshops. Local municipalities, parks departments, and forest preserve districts were also already engaged on the issue of climate change. Therefore, they were primed to participate in the workshops we were offering.

\section{Maintain flow of information and communication throughout the process}

Having a project coordinator was essential to internal project communication throughout the process. This coordinator sent regular emails and set up phone calls to ensure everyone was completing their assignments. We did not have a formal communication plan, however, which may have been helpful in ensuring that we maintained communication with all key project stakeholders. 


Matthews, S.N., Iverson, L.R., Prasad, A.M., Peters, M.P., Rodewald, P.G., 2011. Modifying climate change habitat models using tree speciesspecific assessments of model uncertainty and life history-factors. For. Ecol. Manage. 262, 14601472

Nowak, D.J., Hoehn, R.E., III, Bodine, A.R., Crane, D.E., Dwyer, J.F., Bonnewell, V., Watson, G., 2013. Urban trees and forests of the Chicago region. Resour. Bull. NRS-84. Newtown Square, PA: U.S. Department of Agriculture, Forest Service, Northern Research Station. 106 p.

Ordóñez, C., Duinker, P.N., 2014. Assessing the vulnerability of urban forests to climate change. Environ. Rev. 22, 311-321.

Stoner, A.M.K., Hayhoe, K., Yang, X., Wuebbles, D.J., 2013. An asynchronous regional regression model for statistical downscaling of daily climate variables. International Journal of Climatology 33, 2473-2494.

Swanston, C.W., Janowiak, M.K., eds., 2012. Forest adaptation resources: Climate change tools and approaches for land managers. Gen. Tech. Rep. NRS-87. Newtown Square, PA: U.S. Department of Agriculture, Forest Service, Northern Research Station. 121 p.
Swanston, C.W., Janowiak, M.K, Brandt. L.A., Butler, P.R., Handler, S.D., Shannon, P.D., Derby Lewis, A., Hall, K., Fahey, R.T., Scott, L., Kerber, A., Miesbauer, J.W., Darline, L., 2016. Forest Adaptation Resources: Climate Change Tools and Approaches for Land Managers (2nd Edition). NRS-X. Newtown Square, PA: U.S. Department of Agriculture, Forest Service, Northern Research Station. In Press

The Morton Arboretum. 2015. Northern Illinois Tree Species List. Available online at https://www.mortonarb.org/files/14CT_ NorthernllinoisTreeSpeciesList.pdf

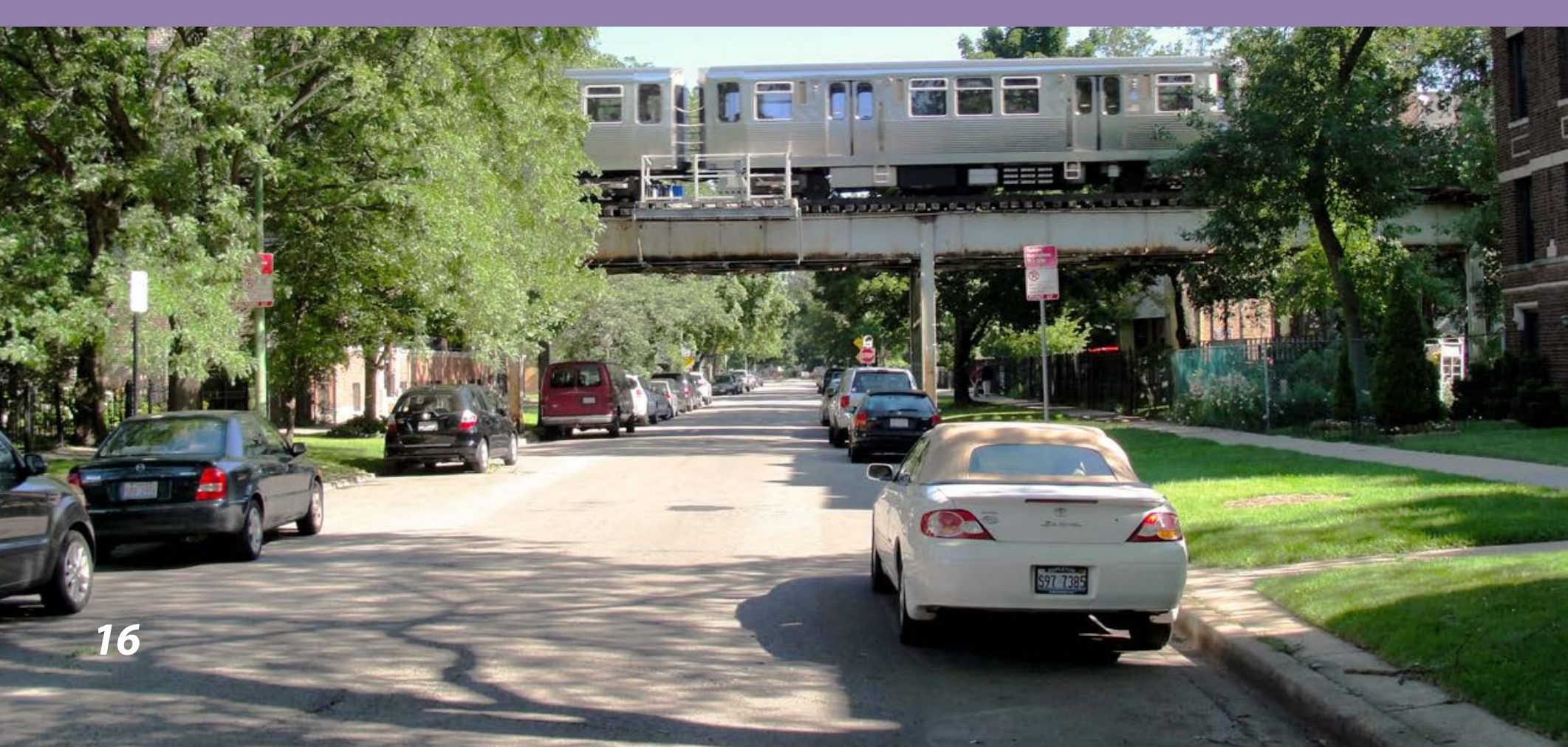


9:10 Workshop objectives and context-Leslie Brandt

Read over objectives

Explain that this is the first of 2 workshops. First we need to know what is vulnerable, then we can adapt.

\section{Part 1: Regional Impacts and Vulnerability Factors}

Each presenter should prepare a 20 minute presentation and leave 5 minutes for discussion.

Leslie introduces each speaker

9:20 Past Climate Change, Climate Projections-Leslie Brandt

9:45 Trees for 2050 Model Results- Andrew Bell and Shannon Still

10:10 Habitat suitability for naturally-occurring species, shifts in hardiness/heat zones-Louis Iverson

10:35 Break (coffee, tea)

10:45 Tree Atlas summaries and I-Tree Model Results -Dave Nowak

11:10 Adaptive Capacity of Urban Trees-Leslie Brandt

\section{Part 2: Assessing Local Vulnerability}

11:30 Assessment Approach Overview -Leslie Brandt

Leslie explains what we will be doing for the rest of the day, and how this fits into adaptation. Defines terms, answers questions. Goes over worksheet.

12:00 Lunch (sandwiches, salads)

1:00 Group Breakouts

Divide larger group into 3 groups:

- Municipalities

- Park Districts

- Forest Preserve Districts

Each group gets a facilitator and note-taker

Facilitators: Leslie, Abigail, Lydia

Notetakers: Melissa, Lindsay, Megan

Groups fill out individual worksheets. Facilitators walk them through the first pass through the worksheet. Each individual records their own responses on their worksheet. Notetakers record overall points not captured in the individual worksheets. After an initial walk-through, individuals can work on their own to complete additional worksheets. Goal: at least 1 worksheet per person is completed by the end of the session, ideally 2-3 (assuming that the first one will be the hard one, and the following will be adjustments 
to that one). In the last 30 minutes of breakouts, individuals share their overall vulnerability rating and subcomponent ratings with the group, and ratings are compared and contrasted.

Facilitator asks:

- Looking over the worksheet factors, are there some that you don't feel will have a large influence on tree growth or survival?

- Which of the factors stand out as having the largest influence and should be given the greatest weight?Are there other factors that we are missing?

- Which factors most strongly contributed to your ratings?

- Are there factors which may interact in such a way that the effects cancel each other out or they multiple the effect?

- In what areas did you have the most confidence in your determination, and in what areas did you have the least?

- For those who completed worksheets for more than 1 area, did some areas stand out as more or less vulnerable, and what factors contributed to that outcome?

(take breaks as needed)

3:15 Group reports (10 minutes per group)

Each group summarizes the key points of what was discussed in their breakouts with the larger group. Other groups ask questions.

3:45 Wrap up and next steps-Leslie

Collect evaluations.

4:00 Adjourn
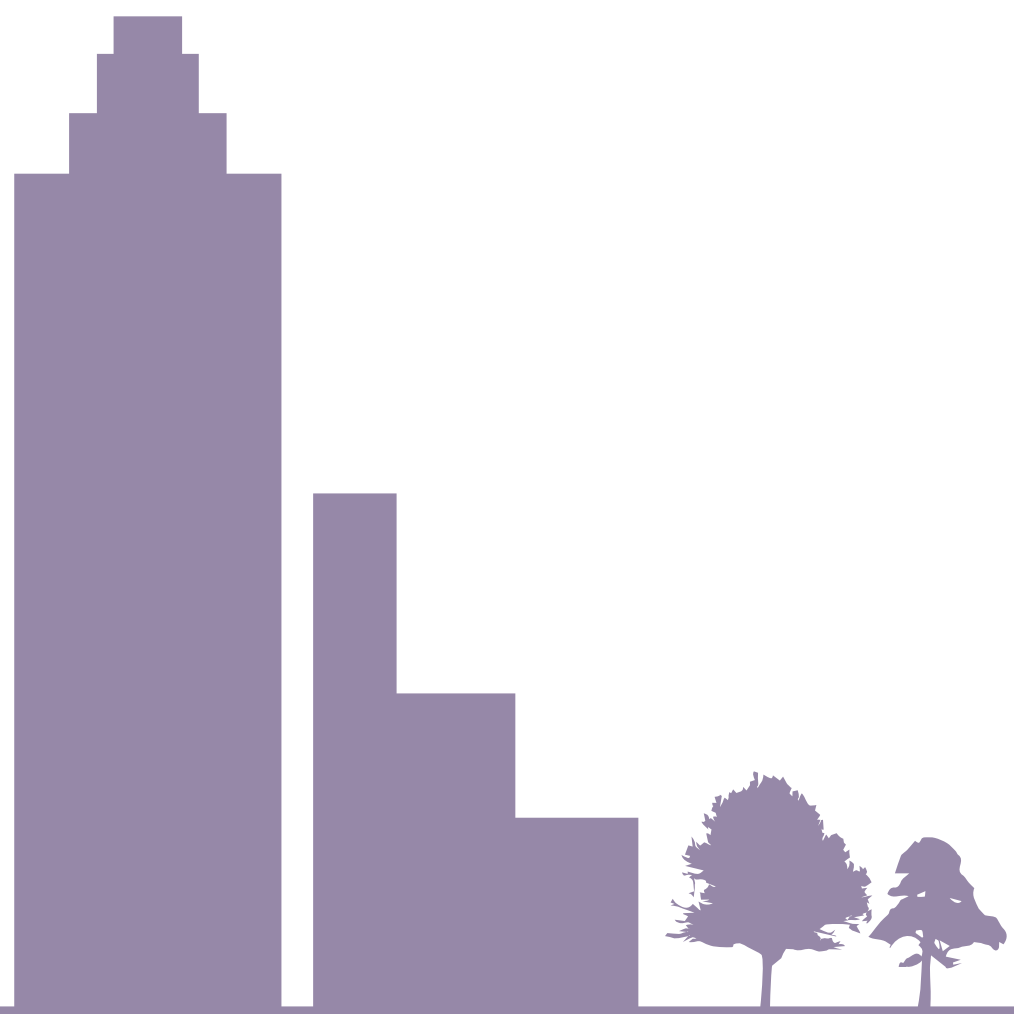


\section{Appendix 2: Urban Forest Vulnerability Worksheet Instructions}

\section{Worksheet Instructions}

A. Read through the list of regional impacts and adaptive capacity factors and their accompanying questions. These questions will prompt you to consider local factors that may modify regional impacts or affect local capacity to adapt to climate change.

\section{B. For each impact or adaptive capacity factor:}

1. Answer yes or no to the question based on any data you have or your personal knowledge/ experience (if you aren't sure, you can give a lower confidence rating). If the question simply does not apply to your area (e.g. a question about residents' tree care and there are no residents), please write N/A.

2. Write down your explanation about whether and how you would expect this to affect your impacts or adaptive capacity to climate change in your area (see glossary).

3. Record the overall effect of the factor on your area's trees and/or forests.

$\downarrow$ Negative effect: You expect this factor to increase mortality, physical damage, or disease/pest susceptibility of your trees or reduce growth and vigor.

$\leftarrow$ Neutral effect: You do not expect this factor to have a negative or positive effect on your trees, or the positive and negative factors will balance out.

个Positive effect: You expect this factor to reduce mortality, physical damage, or disease/pest susceptibility of your trees and/or enhance growth and vigor.

4. Record your confidence in the the direction of the effect you determined in step 3.

Low: You do not have much information to support your conclusion and/or the information is conflicting.

Medium: You have some information which seems to support your conclusion.

High: Your conclusion is supported by area-specific data that all support your conclusion. 

D. Go through your responses and circle the factors you think would have the greatest influence on your area.

\section{Example:}

\begin{tabular}{|c|c|c|c|c|c|}
\hline $\begin{array}{l}\text { Regional } \\
\text { impact }\end{array}$ & $\begin{array}{l}\text { Local } \\
\text { considerations }\end{array}$ & $\begin{array}{l}\text { Yes } \\
\text { or } \\
\text { no }\end{array}$ & Explanation & $\begin{array}{l}\text { Overall } \\
\text { effect }\end{array}$ & Confidence \\
\hline $\begin{array}{l}\text { Heavy rain } \\
\text { events could } \\
\text { increase } \\
\text { flooding, } \\
\text { especially in } \\
\text { the spring. }\end{array}$ & $\begin{array}{l}\text { Is all or part of the area } \\
\text { currently susceptible } \\
\text { to flooding (in a flood } \\
\text { plain and/or has high } \\
\text { number of flood-related } \\
\text { insurance claims)? }\end{array}$ & Yes & $\begin{array}{l}\text { According to FEMA, } \\
\text { only the area within } \\
100 \text { feet of the } \\
\text { Chicago River is at } \\
\text { risk for flooding. } \\
\text { Flood maps are } \\
\text { not up-to-date, } \\
\text { however. }\end{array}$ & $\leftarrow \rightarrow$ & Medium \\
\hline $\begin{array}{l}\text { increased } \\
\text { temperatures } \\
\text { and late- } \\
\text { season } \\
\text { droughts } \\
\text { could increase } \\
\text { susceptibility } \\
\text { to wildfire. }\end{array}$ & $\begin{array}{l}\text { Does the area have a } \\
\text { high density of fuels or } \\
\text { other factors that put it } \\
\text { at risk for wildife? }\end{array}$ & Yes & $\begin{array}{l}\text { Area is heavily } \\
\text { forested and } \\
\text { overstocked with } \\
\text { many declining } \\
\text { trees. }\end{array}$ & $\downarrow$ & High \\
\hline
\end{tabular}

\section{E. For each factor (e.g. physical, biological, human):}

Review the circled positive/negative effects. Determine an overall impact or adaptive capacity rating by placing a mark along a continuous line.

Use your best judgment for the final determination based on the relative weight given to each factor, but as a general guideline:

For impacts:

- Negative Impact: Negative effects outweigh positive effects.

- Moderate Impact: Negative effects are approximately equal to positive effects or most factors are neutral.

- Positive Impact: Positive effects outweigh negative effects.

For adaptive capacity:

- Low Adaptive Capacity: Negative effects outweigh positive effects.

- Moderate Adaptive Capacity: Negative effects are approximately equal to positive effects or most factors are neutral.

- High Adaptive Capacity: Positive effects outweigh negative effects. 


\section{Example:}

Overall influence of human factors (place mark along line):

Negative

Moderate

Positive

\section{For each section:}

Review the overall effects for all factor types to determine an overall rating of impacts and adaptive capacity by placing a mark along a continuous line. In general, this will be an average of all factor types within the section, but use your best judgment for the final determination based on the relative weight given to each factor type.

\section{Example:}

Overall impacts (place mark along line):

Negative

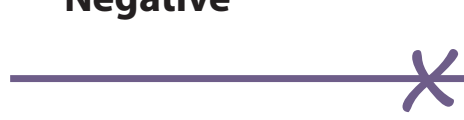

\section{F. Evaluate overall vulnerability:}

Based on your determination of impacts and adaptive capacity, plot your assessment of vulnerability for your area on the figure (as shown in the example to the right).

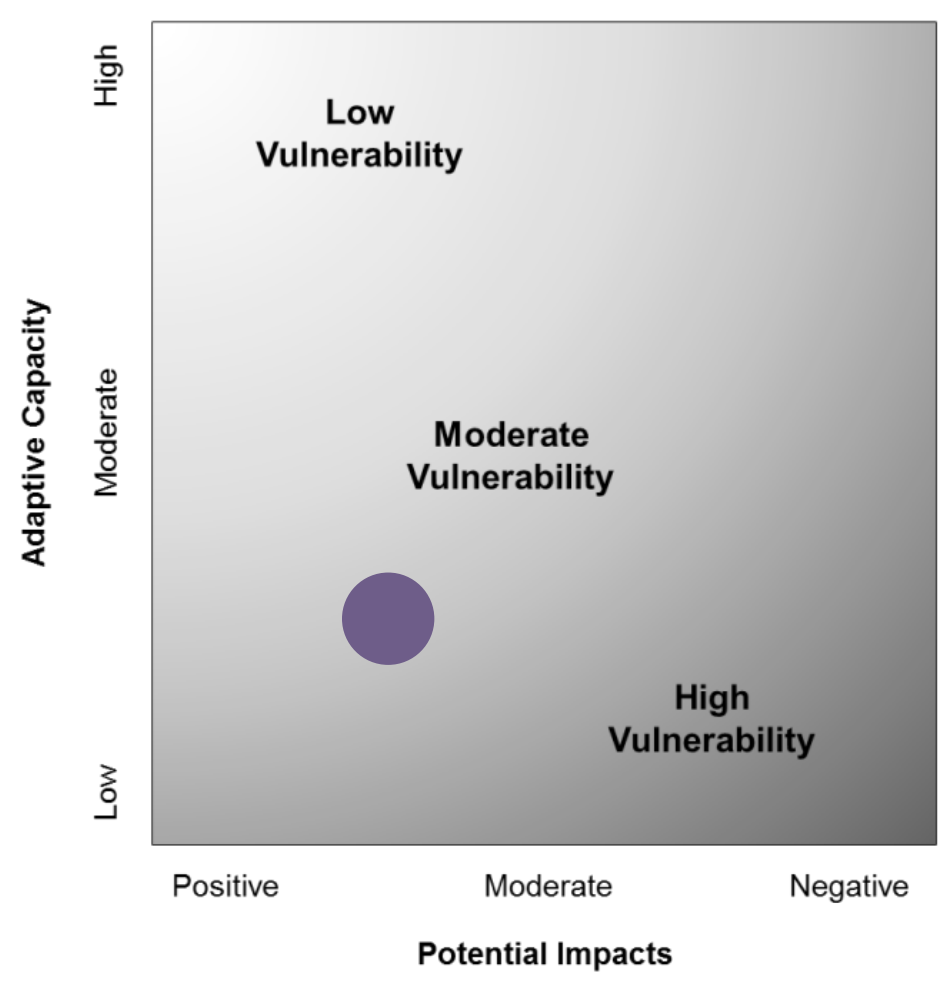




\section{Appendix 3: Urban Forest Vulnerability Worksheet}


Name

Organization/Municipality

Area assessed (e.g. neighborbood, community, county, quadrant, or zone)

\section{Section 1: Impacts}

Impacts are the direct and indirect consequences of climate change on systems. Impacts are a function of a system's exposure to climate change and its sensitivity to any changes. Impacts could be beneficial or harmful to a particular forest or ecosystem type.

Physical Factors

\begin{tabular}{|c|c|c|c|c|c|}
\hline $\begin{array}{l}\text { Regional } \\
\text { impact }\end{array}$ & $\begin{array}{l}\text { Local } \\
\text { considerations }\end{array}$ & $\begin{array}{l}\text { Yes } \\
\text { or } \\
\text { no }\end{array}$ & Explanation & $\begin{array}{l}\text { Overall } \\
\text { effect }\end{array}$ & Confidence \\
\hline $\begin{array}{l}\text { Heavy rain events } \\
\text { could increase } \\
\text { flooding, especially in } \\
\text { the spring. }\end{array}$ & $\begin{array}{l}\text { Is all or part of the area currently } \\
\text { susceptible to flooding (in a flood } \\
\text { plain and/or has high number of } \\
\text { flood-related insurance claims)? }\end{array}$ & & & & \\
\hline $\begin{array}{l}\text { Increases in } \\
\text { precipitation could } \\
\text { lead to increased soil } \\
\text { moisture in the winter } \\
\text { and spring. }\end{array}$ & $\begin{array}{l}\text { Are the soils in your area well or } \\
\text { poorly drained compared to the } \\
\text { rest of the region? }\end{array}$ & & & & \\
\hline $\begin{array}{l}\text { Decreases in summer } \\
\text { or fall precipitation } \\
\text { could lead to } \\
\text { decreases in soil } \\
\text { moisture. }\end{array}$ & $\begin{array}{l}\text { Are the soils in your area well or } \\
\text { poorly drained compared to the } \\
\text { rest of the region? }\end{array}$ & & & & \\
\hline $\begin{array}{l}\text { Heavy storm events } \\
\text { may increase and } \\
\text { tornado seasons may } \\
\text { shift. }\end{array}$ & $\begin{array}{l}\text { Is your area particularly } \\
\text { susceptible to wind or tornadoes } \\
\text { compared to the rest of the } \\
\text { region? }\end{array}$ & & & & \\
\hline $\begin{array}{l}\text { Temperatures have } \\
\text { increased more } \\
\text { dramatically in the } \\
\text { counties directly } \\
\text { adjacent to Lake } \\
\text { Michigan over the } \\
\text { past } 100 \text { years. }\end{array}$ & $\begin{array}{l}\text { Is your area along the shores of } \\
\text { Lake Michigan? }\end{array}$ & & & & \\
\hline $\begin{array}{l}\text { Snow may increase on } \\
\text { the east side of Lake } \\
\text { Michigan. }\end{array}$ & $\begin{array}{l}\text { Is your area on the east side of } \\
\text { Lake Michigan? }\end{array}$ & & & & \\
\hline & & & & & \\
\hline & & & & & \\
\hline & & & & & \\
\hline
\end{tabular}


Overall influence of physical factors (place mark along line):

Negative

Moderate

Positive

Biological Factors

\begin{tabular}{|c|c|c|c|c|c|}
\hline $\begin{array}{l}\text { Regional } \\
\text { impact }\end{array}$ & $\begin{array}{l}\text { Local } \\
\text { considerations }\end{array}$ & $\begin{array}{l}\text { Yes } \\
\text { or } \\
\text { no }\end{array}$ & Explanation & $\begin{array}{l}\text { Overall } \\
\text { effect }\end{array}$ & Confidence \\
\hline $\begin{array}{l}\text { Many trees, especially } \\
\text { at the southern } \\
\text { end of their natural } \\
\text { or planted range, } \\
\text { are expected } \\
\text { to experience a } \\
\text { reduction in habitat } \\
\text { suitability. }\end{array}$ & $\begin{array}{l}\text { Based on the model projections, } \\
\text { are many of the dominant trees } \\
\text { in your area expected to have a } \\
\text { reduction in habitat suitability } \\
\text { and/or be otherwise vulnerable } \\
\text { to climate change and associated } \\
\text { stressors? }\end{array}$ & & & & \\
\hline $\begin{array}{l}\text { Many trees, especially } \\
\text { at the northern } \\
\text { end of their natural } \\
\text { or planted range, } \\
\text { are expected to } \\
\text { experience an } \\
\text { increase in habitat } \\
\text { suitability. }\end{array}$ & $\begin{array}{l}\text { Based on the model projections, } \\
\text { are many of the dominant trees } \\
\text { in your area expected to have } \\
\text { an increase in habitat suitability } \\
\text { and/or have low vulnerability to } \\
\text { climate change? }\end{array}$ & & & & \\
\hline $\begin{array}{l}\text { Many pests and } \\
\text { pathogens are } \\
\text { expected to benefit } \\
\text { from longer growing } \\
\text { seasons and warmer } \\
\text { temperatures. }\end{array}$ & $\begin{array}{l}\text { Is your area currently } \\
\text { experiencing a pest or disease } \\
\text { outbreak of one or more pests/ } \\
\text { pathogens that could benefit } \\
\text { from projected changes in } \\
\text { climate? }\end{array}$ & & & & \\
\hline $\begin{array}{l}\text { Some pests or } \\
\text { pathogens that prefer } \\
\text { cool, wet conditions } \\
\text { may decrease. }\end{array}$ & $\begin{array}{l}\text { Is your area currently } \\
\text { experiencing a pest or disease } \\
\text { outbreak of one or more pests/ } \\
\text { pathogens that could see a } \\
\text { reduction in favorable conditions } \\
\text { from projected changes in } \\
\text { climate? }\end{array}$ & & & & \\
\hline $\begin{array}{l}\text { Warmer winters could } \\
\text { be beneficial to some } \\
\text { herbivores. }\end{array}$ & $\begin{array}{l}\text { Is your area particularly } \\
\text { vulnerable to herbivory from } \\
\text { deer or other wildlife? }\end{array}$ & & & & \\
\hline $\begin{array}{l}\text { As temperatures } \\
\text { increase, suitable } \\
\text { habitat for many } \\
\text { invasive species could } \\
\text { increase. }\end{array}$ & $\begin{array}{l}\text { Are invasive plant species } \\
\text { outcompeting native and/or } \\
\text { desired planted species in your } \\
\text { area? }\end{array}$ & & & & \\
\hline $\begin{array}{l}\text { Temperatures are } \\
\text { projected to increase. }\end{array}$ & $\begin{array}{l}\text { Tree canopy cover can reduce } \\
\text { local temperatures by creating } \\
\text { shade and contributing to } \\
\text { evaporative cooling. Are tree } \\
\text { cover and/or density at or near } \\
\text { desired levels for your area? }\end{array}$ & & & & \\
\hline
\end{tabular}




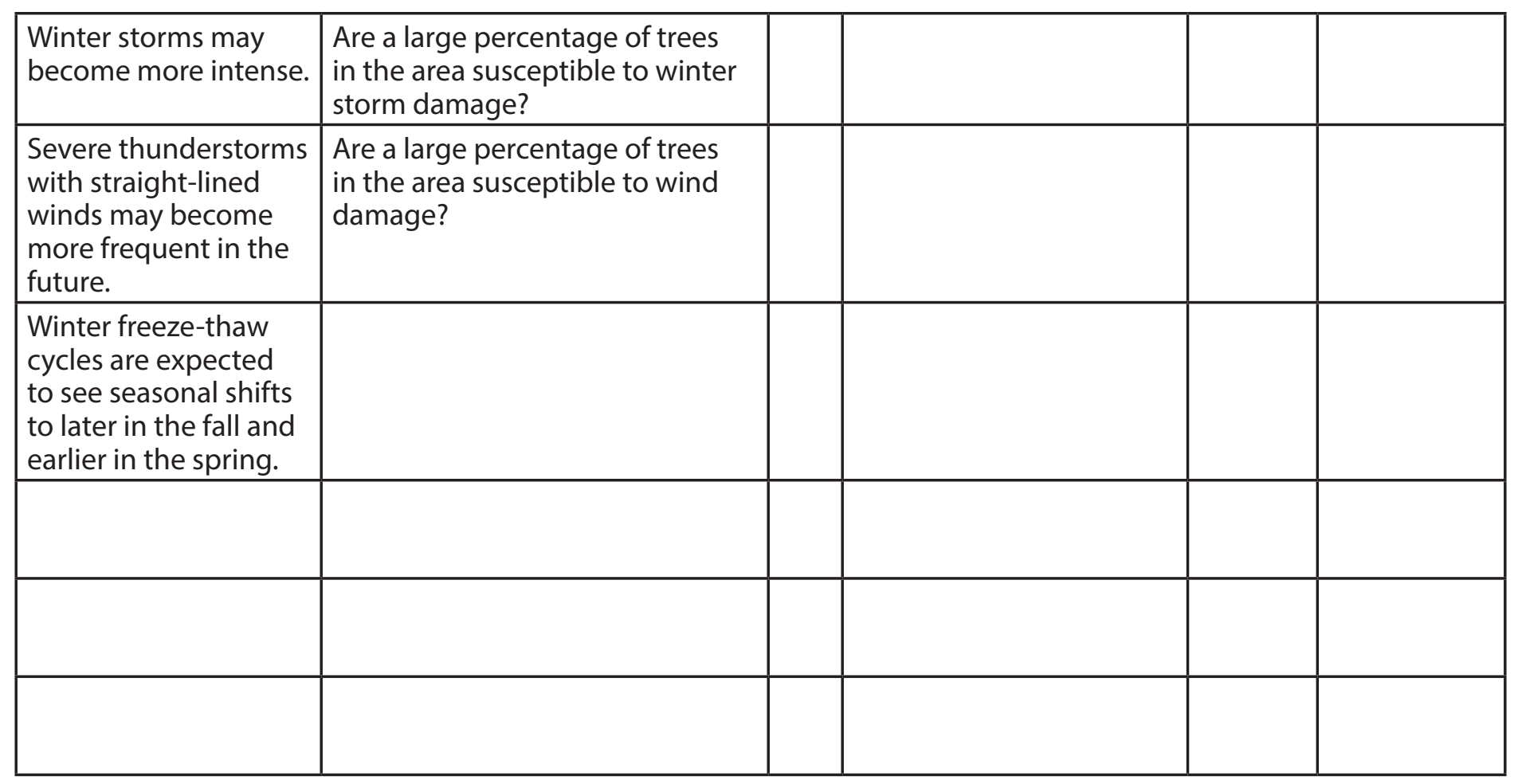

Overall impacts of biological factors (place mark along line):

$\begin{array}{lll}\text { Negative } & \text { Moderate } & \text { Positive }\end{array}$

Human-Influenced Factors

\begin{tabular}{|l|l|l|l|l|l|}
\hline $\begin{array}{l}\text { Regional } \\
\text { impact }\end{array}$ & $\begin{array}{l}\text { Local } \\
\text { considerations }\end{array}$ & $\begin{array}{l}\text { Yes } \\
\text { or } \\
\text { no }\end{array}$ & Explanation & $\begin{array}{l}\text { Overall } \\
\text { effect }\end{array}$ & Confidence \\
\hline $\begin{array}{l}\text { Temperatures are } \\
\text { projected to increase. }\end{array}$ & $\begin{array}{l}\text { Does your area experience a } \\
\text { strong urban heat island effect } \\
\text { that could make it warmer than } \\
\text { the surrounding area? }\end{array}$ & & & & \\
\hline $\begin{array}{l}\text { Increased } \\
\text { temperatures and } \\
\text { longer growing } \\
\text { seasons could lead } \\
\text { to increased ozone } \\
\text { pollution. }\end{array}$ & $\begin{array}{l}\text { Does your area have higher levels } \\
\text { of air pollution from automobiles } \\
\text { or industry compared to the } \\
\text { region as a whole? }\end{array}$ & & & & \\
\hline $\begin{array}{l}\text { Increased heavy } \\
\text { precipitation events } \\
\text { could increase runoff, } \\
\text { leading to shifts in } \\
\text { local soil and water } \\
\text { pollution. }\end{array}$ & $\begin{array}{l}\text { Does your area have relatively } \\
\text { high levels of soil or water } \\
\text { pollution (e.g. from agricultural } \\
\text { or industrial sources)? }\end{array}$ & & & & \\
\hline
\end{tabular}




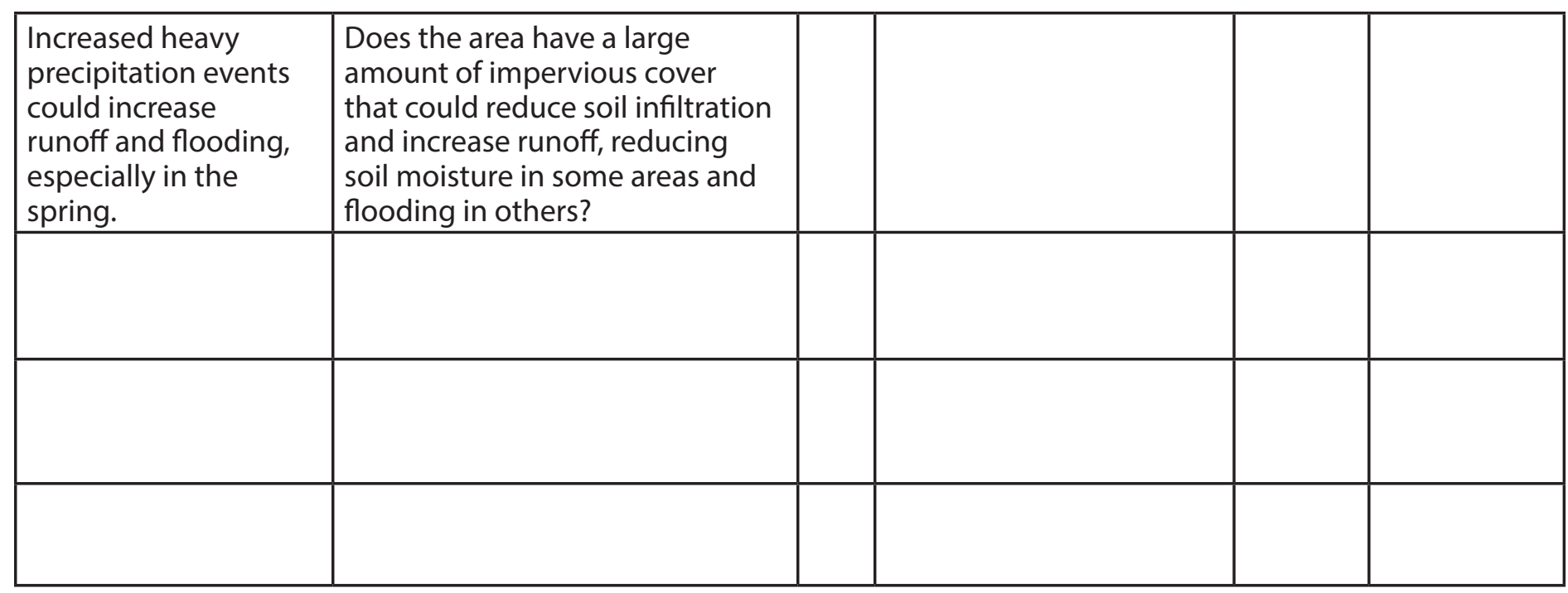

Overall impacts of human-influenced factors (place mark along line):

Negative

Moderate

Positive

Overall Impacts:

Negative

Moderate

Positive

\section{Section 2: Adaptive Capacity}

Adaptive capacity is the ability of a system to accommodate or cope with potential climate change impacts with minimal disruption. This could be intrinsic to the organism (ability to acclimate).

Biological Factors

\begin{tabular}{|c|c|c|c|c|c|}
\hline $\begin{array}{l}\text { Adaptive Capacity } \\
\text { Factor }\end{array}$ & $\begin{array}{l}\text { Local } \\
\text { considerations }\end{array}$ & $\begin{array}{l}\text { Yes } \\
\text { or } \\
\text { no }\end{array}$ & Explanation & $\begin{array}{l}\text { Overall } \\
\text { effect }\end{array}$ & Confidence \\
\hline $\begin{array}{l}\text { Species-rich } \\
\text { communities have } \\
\text { exhibited greater } \\
\text { resilience to extreme } \\
\text { environmental } \\
\text { conditions and } \\
\text { greater potential } \\
\text { to recover from } \\
\text { disturbance. }\end{array}$ & $\begin{array}{l}\text { Is there a high level of diversity of } \\
\text { tree species in your area (e.g. no } \\
\text { more than } 20 \% \text { from one family, } \\
10 \% \text { of one genus, } 5 \% \text { of one } \\
\text { species)? }\end{array}$ & & & & \\
\hline
\end{tabular}




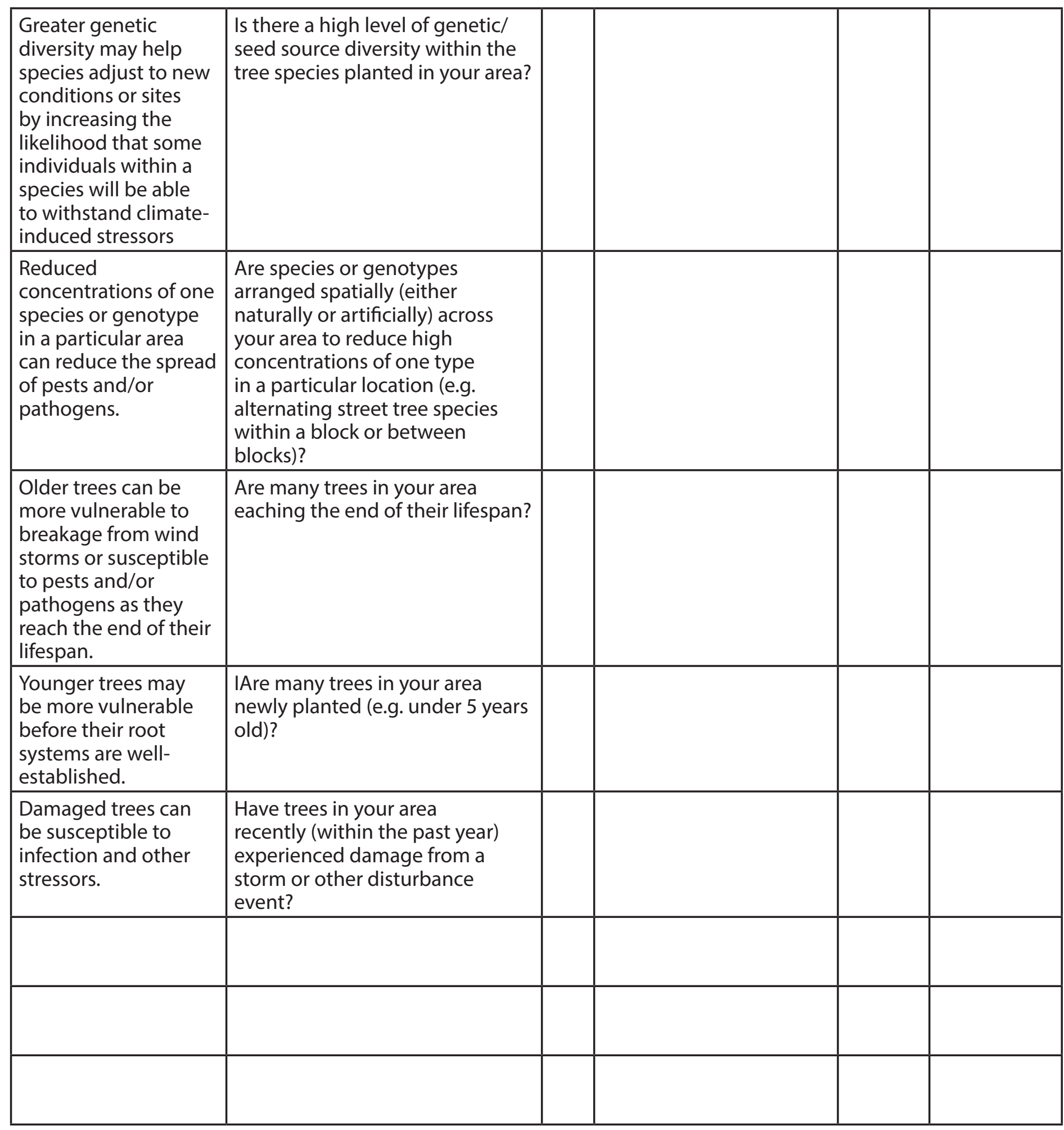

Overall biological adaptive capacity (place mark along line):

Low

Moderate

High 
Organizational/Technical Factors

\begin{tabular}{|c|c|c|c|c|c|}
\hline $\begin{array}{l}\text { Adaptive Capacity } \\
\text { Factors }\end{array}$ & $\begin{array}{l}\text { Local } \\
\text { considerations }\end{array}$ & $\begin{array}{l}\text { Yes } \\
\text { or } \\
\text { no }\end{array}$ & Explanation & $\begin{array}{l}\text { Overall } \\
\text { effect }\end{array}$ & Confidence \\
\hline $\begin{array}{l}\text { Trained forestry } \\
\text { professionals may } \\
\text { be more likely to } \\
\text { recognize potential } \\
\text { problems and identify } \\
\text { appropriate solutions. }\end{array}$ & $\begin{array}{l}\text { Is your area currently overseen } \\
\text { by a tree board and/or } \\
\text { department staffed with forestry } \\
\text { professionals? }\end{array}$ & & & & \\
\hline $\begin{array}{l}\text { Tree care ordinances } \\
\text { can be helpful } \\
\text { in ensuring best } \\
\text { practices when } \\
\text { followed unless they } \\
\text { are not updated } \\
\text { in light of new } \\
\text { information. }\end{array}$ & $\begin{array}{l}\text { Is a tree care ordinance or } \\
\text { planting list in place that is } \\
\text { sufficiently flexible to allow for } \\
\text { adjustments in species in light of } \\
\text { climate change? }\end{array}$ & & & & \\
\hline $\begin{array}{l}\text { A diverse mix } \\
\text { of species and } \\
\text { genotypes relies } \\
\text { on the availability } \\
\text { of young trees for } \\
\text { planting. }\end{array}$ & $\begin{array}{l}\text { Are current nursery suppliers able } \\
\text { to provide a wide mix of species } \\
\text { and cultivars? }\end{array}$ & & & & \\
\hline $\begin{array}{l}\text { Knowing the mix of } \\
\text { species, age classes, } \\
\text { and conditions } \\
\text { of trees can help } \\
\text { determine how } \\
\text { many trees could be } \\
\text { vulnerable. }\end{array}$ & $\begin{array}{l}\text { Does your area have a current } \\
\text { and comprehensive tree } \\
\text { inventory? }\end{array}$ & & & & \\
\hline $\begin{array}{l}\text { Long-term plans } \\
\text { can be helpful in } \\
\text { identifying goals } \\
\text { and objectives, as } \\
\text { long as they can be } \\
\text { adjusted given new } \\
\text { information. }\end{array}$ & $\begin{array}{l}\text { Does your area have a long-term } \\
\text { plan (such as a tree management } \\
\text { plan, or similar) that is sufficiently } \\
\text { flexible to allow for adjustments } \\
\text { in species in light of climate } \\
\text { change? }\end{array}$ & & & & \\
\hline $\begin{array}{l}\text { A disaster response/ } \\
\text { recovery plan can } \\
\text { help ensure that } \\
\text { damaged trees are } \\
\text { properly managed } \\
\text { and replaced with } \\
\text { a resilient mix } \\
\text { of trees that are } \\
\text { properly planted and } \\
\text { maintained. }\end{array}$ & $\begin{array}{l}\text { Does your area currently have a } \\
\text { disaster recovery/response plan? }\end{array}$ & & & & \\
\hline $\begin{array}{l}\text { Trees that are } \\
\text { properly watered } \\
\text { and fertilized are less } \\
\text { likely to experience } \\
\text { disease, mortality, and } \\
\text { drought stress. }\end{array}$ & $\begin{array}{l}\text { Are the majority of trees in the } \\
\text { area receiving routine care and } \\
\text { maintenance? }\end{array}$ & & & & \\
\hline
\end{tabular}




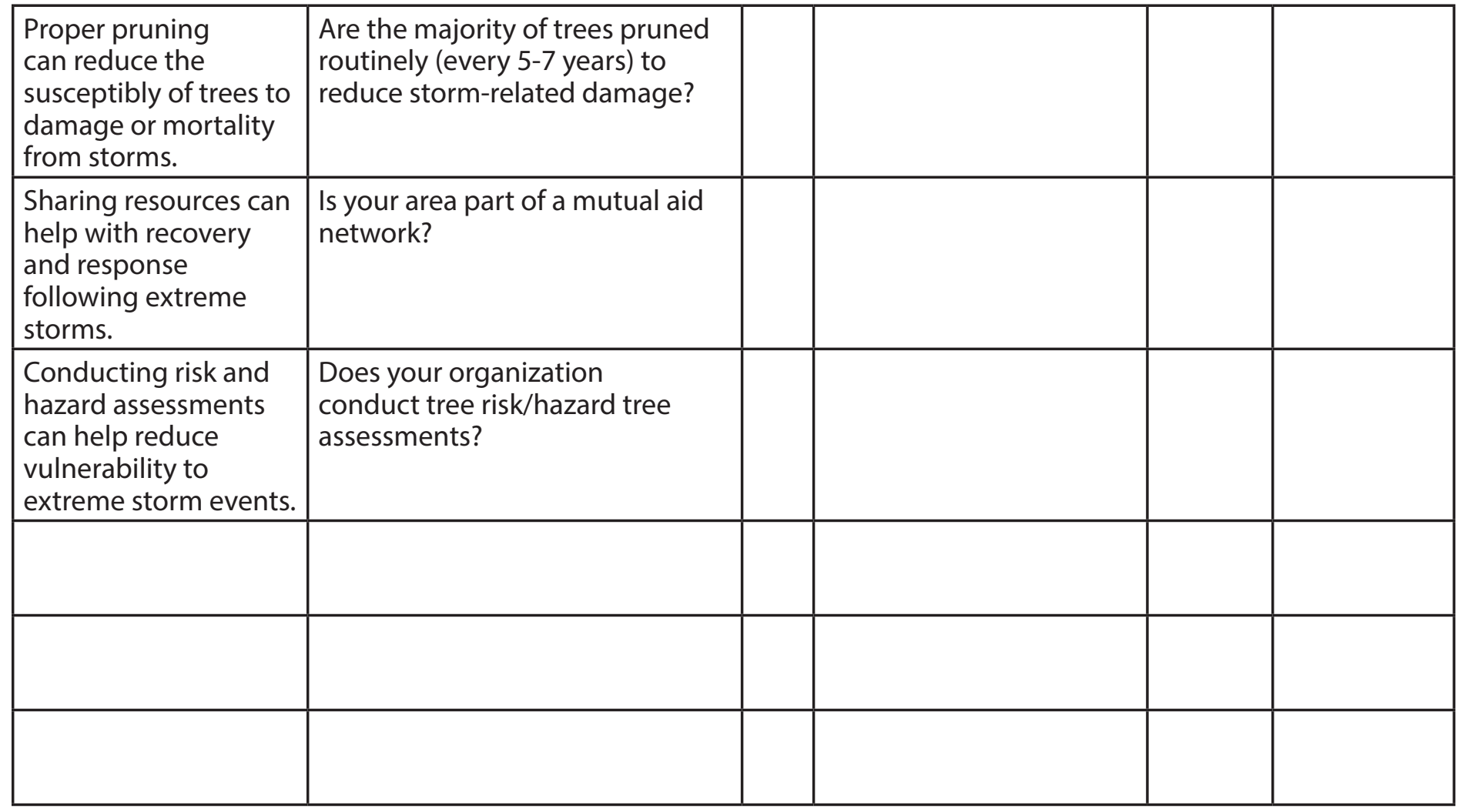

Overall organizational/technical adaptive capacity (place mark along line):

Low Moderate

High

Economic Factors

\begin{tabular}{|l|l|l|l|l|l|}
\hline $\begin{array}{l}\text { Adaptive Capacity } \\
\text { Factors }\end{array}$ & $\begin{array}{l}\text { Local } \\
\text { considerations }\end{array}$ & $\begin{array}{l}\text { Yes } \\
\text { or } \\
\text { no }\end{array}$ & Notes & $\begin{array}{l}\text { Overall } \\
\text { effect }\end{array}$ & Confidence \\
\hline $\begin{array}{l}\text { As trees die, planting } \\
\text { new trees presents } \\
\text { an opportunity to } \\
\text { increase diversity and } \\
\text { plant more resilient } \\
\text { species. }\end{array}$ & $\begin{array}{l}\text { Is there sufficient funding to } \\
\text { purchase and plant new trees } \\
\text { to replace each one that is lost } \\
\text { (excluding recent EAB-related } \\
\text { funding issues)? }\end{array}$ & & & & \\
\hline $\begin{array}{l}\text { Proper care and } \\
\text { maintenance } \\
\text { can reduce the } \\
\text { vulnerability of } \\
\text { existing trees. }\end{array}$ & $\begin{array}{l}\text { Is there sufficient funding to } \\
\text { maintain existing street trees and } \\
\text { those on public lands? }\end{array}$ & & & & \\
\hline $\begin{array}{l}\text { Proper care and } \\
\text { maintenance } \\
\text { can reduce the } \\
\text { vulnerability of } \\
\text { existing trees. }\end{array}$ & $\begin{array}{l}\text { Do private landowners } \\
\text { (homeowners, businesses) in } \\
\text { your area have sufficient financial } \\
\text { resources to plant and care for } \\
\text { trees? }\end{array}$ & & & & \\
\hline
\end{tabular}




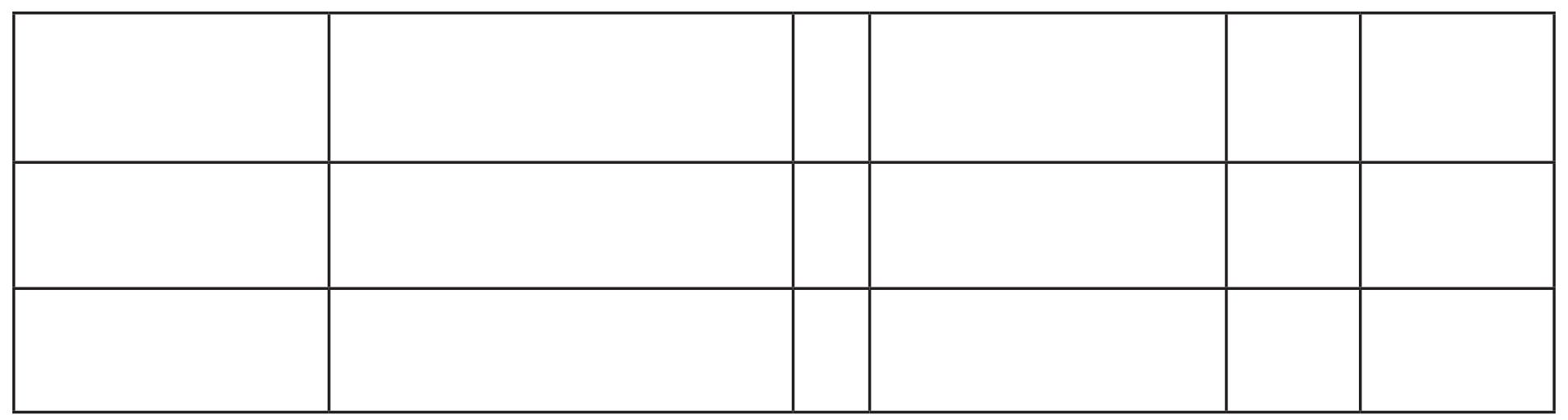

Overall economic adaptive capacity (place mark along line):

Low

Moderate

High

Social Factors

\begin{tabular}{|l|l|l|l|l|l|}
\hline Adaptive Capacity & $\begin{array}{l}\text { Local } \\
\text { Factors }\end{array}$ & $\begin{array}{l}\text { Yes } \\
\text { or } \\
\text { no }\end{array}$ & $\begin{array}{l}\text { Climate Change } \\
\text { Considerations }\end{array}$ & $\begin{array}{l}\text { Overall } \\
\text { effect }\end{array}$ & Confidence \\
\hline $\begin{array}{l}\text { Residents who value } \\
\text { trees are more likely } \\
\text { to care for them. }\end{array}$ & $\begin{array}{l}\text { Do residents in your area value } \\
\text { trees as an important resource? }\end{array}$ & & & & \\
\hline $\begin{array}{l}\text { Even if funding } \\
\text { is limited, a large } \\
\text { volunteer base can } \\
\text { help reduce costs and } \\
\text { increase awareness } \\
\text { about trees and tree } \\
\text { care. }\end{array}$ & $\begin{array}{l}\text { Is there a sufficient volunteer } \\
\text { base to aid in the planting and } \\
\text { care of trees in the area? }\end{array}$ & & & & \\
\hline $\begin{array}{l}\text { Organizations can } \\
\text { help find and pool } \\
\text { resources to help care } \\
\text { for and plant trees. }\end{array}$ & $\begin{array}{l}\text { Is there an active network of } \\
\text { organizations engaged in caring } \\
\text { for forest resources in your area? }\end{array}$ & & & & \\
\hline $\begin{array}{l}\text { Incentives can } \\
\text { increase public } \\
\text { participation and } \\
\text { interest. }\end{array}$ & $\begin{array}{l}\text { Are any public incentive } \\
\text { programs in place to encourage } \\
\text { the planting and/or care of trees? }\end{array}$ & & & & \\
\hline & & & & & \\
\hline
\end{tabular}


Overall social adaptive capacity (place mark along line):

Low

Moderate

High

\section{Overall Adaptive Capacity Rating:}

Low

Moderate

High

\section{Section 3: Vulnerability}

Vulnerability is the susceptibility of a system to the adverse effects of climate change. It is a function of its potential impacts and its adaptive capacity.

Based on your determination of impacts and adaptive capacity, plot your assessment of vulnerability for your area on the figure.

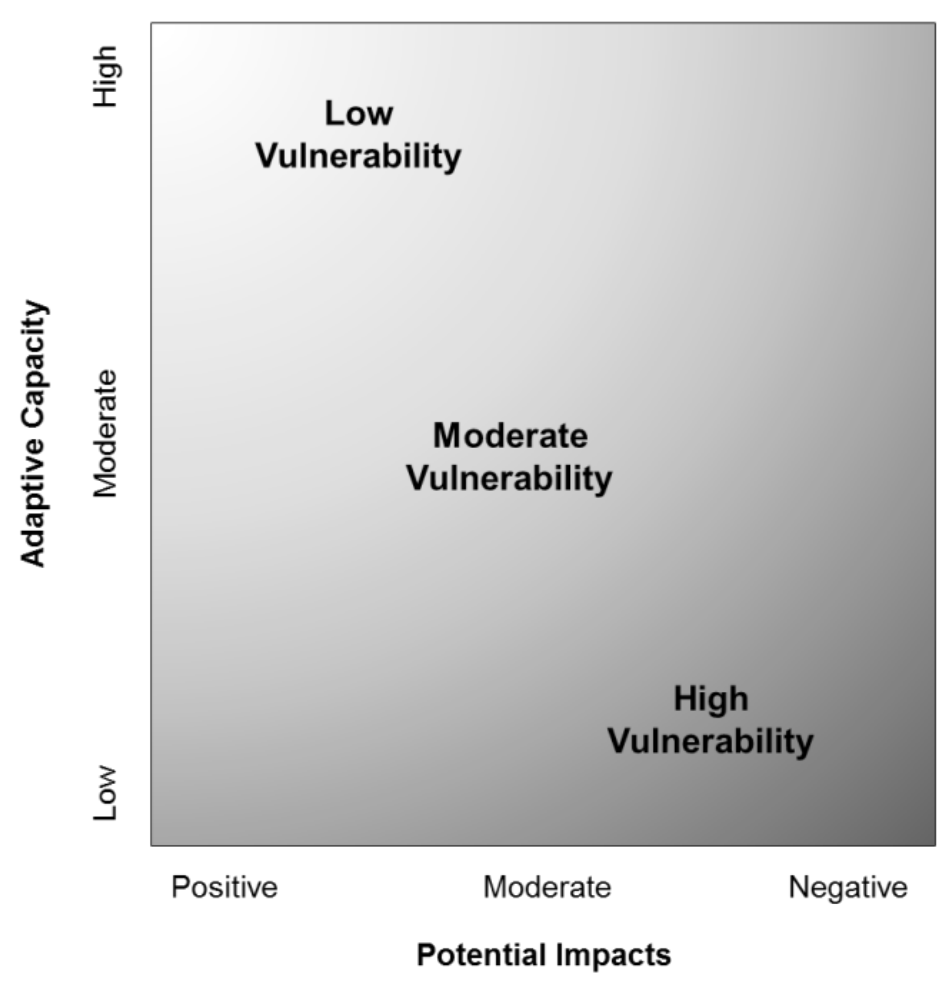


- Describe the purpose of Step 3 and detail what type of information goes in each of the columns. Provide tips for completing the worksheet. Explain that it's okay to jump ahead to later steps (adaptation actions/tactics) — just write it down and come back.

- Give example

\section{0:15 Step 3 -- Breakouts}

Draft/complete Step 3.

Breakouts (60 min)

Participants divide into their groups to work on Step 3.

Divide group up into three groups (parks, municipalities, forest preserves), with one facilitator each.

- They should transfer over the goals/objectives from step 1.

- If they have a lot of goals/objectives, encourage them to just start with 2-3

- Challenges and opportunities should be related to CLIMATE CHANGE. Some of these will have come up in their vulnerability assessments. Encourage them to review those (and step 2) for ideas if they are stuck.

- Give them time to work on their own, and maybe check in every now and then to see how things are going. Maybe have them share some of what they are thinking with the rest of the group.

- If it seems like they are stuck, here are some leading questions:

- If invasive species start producing seed earlier in the year, how will that affect their management?

- How would a shorter winter affect pruning?

- If summers are dry, how would that affect your success rate for newly planted trees?

Are there species you are thinking of planting or managing for that may not do well under projected change? Are there others that may do better?

\section{1:15 Step 3 -- Whole group discussion}

Review major challenges and opportunities from climate change among the entire group.

Activity

3 green and 3 red sticky notes will be handed out to each participant during the breakout session. Markers will be set out for them to write with. Each participant should:

- put top 3 challenges on red sticky notes,

- $\quad$ put top 3 opportunities on green sticky notes.

Call on each participant to briefly state their challenges and opportunities and hand you the stick notes. We'll set up one section for challenges and one for opportunities. As more come up, group like things together, and see if there are themes that emerge.

Questions: (record answers on flip charts, notetakers can take more detailed notes)

- What are some major themes that emerged for challenges?

- How do these differ for more urban/developed areas compared to natural areas?

- How many of these challenges are organizational, technical, economic, social, or political?

- After looking at all of these, what stands out to you?

- What are the major opportunities you found? 
- Are these different for different types of lands?

- Overall, do you feel that the challenges or the opportunities are greater?

- Given these challenges and opportunities, who changed their management objectives (i.e., which management objectives weren't feasible)? Or did you keep them the same? Which ones might change in the future and why (i.e., at what point might management objectives not be feasible)?

Point out that this step is okay for not making big changes, but just thinking about the potential implications of climate change impacts. It's important to slow down and consider; you may not make changes now, but that's an important thought. Likewise, you may identify a point in the future where you would change your objectives.

\section{1:45 Lunch}

\section{2:30 Urban Forestry Adaptation Strategies and Approaches - Presentation}

Introduce/review the menu of Strategies and Approaches

Adaptation Options presentation (5-10 minutes)

Describe resistance, resilience, and transition how they are different trajectories.

Urban Forestry Strategies/Approaches Presentation (15 min)

Briefly describe each of the Strategies, and how each strategy has several related approaches. Focus on different type of clumps-idea that you can pick-and-choose, but have to be thoughtful about it.

Step 4 Overview and examples (15 min)

Describe the purpose of Step 4 and detail what type of information goes in each of the columns. Provide tips for completing the worksheet. Explain that it's okay to go back or jump ahead to later steps-just write it down and come back.

\section{1:15 Step 4 - Breakouts}

Groups work on Step 4. Keep step 5 in mind and bin items as needed.

- Help them find the 1-page list of strategies and approaches in their packet

- If they already have some specific on the ground actions they are planning, have them write down tactics first, then find the strategies/approaches for which those tactics apply.

- If they don't have specific on the ground actions, have them start with strategies/approaches, and then think about tactics.

- The list generally goes from the more resistance-oriented to more transition-oriented, so suggest they select a few from the bottom of the list if they want to think more about future climate.

- Copies of the adaptive capacity factors and model results for particular tree species are available at each table if people are interested in what specific species they should favor/disfavor.

- For this step, benefits and drawbacks can be related to ANYTHING, not just climate change.

- Give them time to work on their own, and maybe check in every now and then to see how things are going. Maybe have them share some of what they are thinking with the rest of the group.

\section{2:30 Step 4 - Whole Group}

Questions: 
- How many of the potential adaptation actions did you evaluate, and of these how many did you ultimately select?

- Of the ones that you did not select, do you think that you might implement these in the future? If so, when? Why?

- When you look at all of the actions that you selected, do they add up and address your biggest challenges?

- Did you think of an action that wasn't captured by one of the Strategies or Approaches?

- Looking at the strategies selected, would you say your strategies are more resistance, resilience, or response/transition-oriented, or are they a mix?

\section{3:00 Monitoring}

Explain step 5 (monitoring), which can be completed on their own.

\section{3:15 Next steps}

Have group discuss their plans. See where decisions were similar/different. Discuss opportunities for coordination, learning, or shared resources. Collect ideas on flipcharts or white board.

Describe next steps and expectations for moving forward. In some ways, next part is the hardest part to get going. We will be checking in a few weeks after the workshop to see how things are going, what you've been thinking, and what you need. We are there to provide help. We'll check in periodically to see how things are going as long as you are interested.

Next step discussion topics (record on flip charts, have notetakers take more notes)

- What are 5 ways that you'll use the ideas and resources that you've learned about through this training in your everyday work once you return to the office/field? [Give a few minutes to write those down, followed by discussion]

- What are some ways that you would talk with your colleagues (or clients) about climate change and adaptation?

- What will it take for this thought process to become a natural part of your forest management and planning?

- Would it be helpful to have some type of community of practice to share ideas among this group, or other demonstration projects?

Opportunities for funding

Goodbye/Thank you

Give time for and Collect Evaluations

\section{4:00 Adjourn}




\section{Abstract}

Many urban foresters have recognized the need to incorporate climate change considerations into urban forest management, but often lack the specialized training or knowledge to explicitly address this in their planning and practices. This document describes a framework we developed and piloted in the Chicago region to assess the vulnerability of urban forests and incorporate that information into on-the-ground actions. We describe the three steps used to implement this project and the lessons learned from this process.

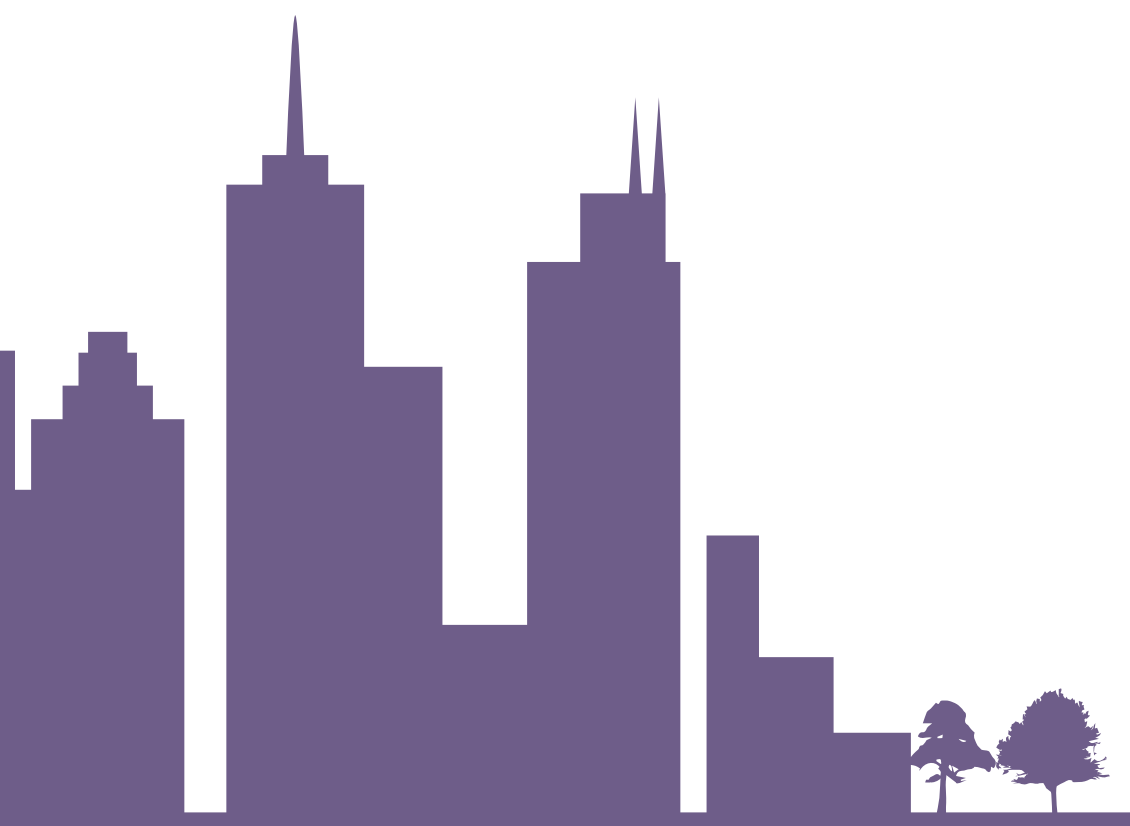

